\title{
Global atmospheric budget of acetaldehyde: 3-D model analysis and constraints from in-situ and satellite observations
}

\author{
D. B. Millet ${ }^{1}$, A. Guenther ${ }^{2}$, D. A. Siegel ${ }^{3}$, N. B. Nelson ${ }^{3}$, H. B. Singh ${ }^{4}$, J. A. de Gouw ${ }^{5}$, C. Warneke ${ }^{5}$, J. Williams ${ }^{6}$,

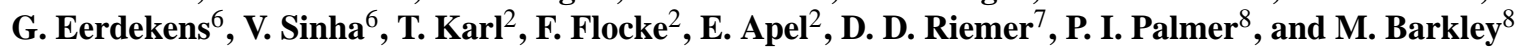 \\ ${ }^{1}$ University of Minnesota, Department of Soil, Water and Climate, St. Paul, Minnesota, USA \\ ${ }^{2}$ NCAR, Atmospheric Chemistry Division, Boulder, Colorado, USA \\ ${ }^{3}$ University of California, Santa Barbara, Institute for Computational Earth System Science, Santa Barbara, California, USA \\ ${ }^{4}$ NASA Ames Research Center, Moffett Field, California, USA \\ ${ }^{5}$ NOAA ESRL, Boulder, Colorado, USA \\ ${ }^{6}$ Max Planck Institute for Chemistry, Mainz, Germany \\ ${ }^{7}$ University of Miami, Rosenstiel School of Marine and Atmospheric Science, Miami, Florida, USA \\ ${ }^{8}$ University of Edinburgh, School of GeoSciences, Edinburgh, UK
}

Received: 2 November 2009 - Published in Atmos. Chem. Phys. Discuss.: 12 November 2009

Revised: 28 March 2010 - Accepted: 29 March 2010 - Published: 12 April 2010

\begin{abstract}
We construct a global atmospheric budget for acetaldehyde using a 3-D model of atmospheric chemistry (GEOS-Chem), and use an ensemble of observations to evaluate present understanding of its sources and sinks. Hydrocarbon oxidation provides the largest acetaldehyde source in the model $\left(128 \mathrm{Tg} \mathrm{a}^{-1}\right.$, a factor of 4 greater than the previous estimate), with alkanes, alkenes, and ethanol the main precursors. There is also a minor source from isoprene oxidation. We use an updated chemical mechanism for GEOSChem, and photochemical acetaldehyde yields are consistent with the Master Chemical Mechanism. We present a new approach to quantifying the acetaldehyde air-sea flux based on the global distribution of light absorption due to colored dissolved organic matter (CDOM) derived from satellite ocean color observations. The resulting net ocean emission is $57 \mathrm{Tg} \mathrm{a}^{-1}$, the second largest global source of acetaldehyde. A key uncertainty is the acetaldehyde turnover time in the ocean mixed layer, with quantitative model evaluation over the ocean complicated by known measurement artifacts in clean air. Simulated concentrations in surface air over the ocean generally agree well with aircraft measurements, though the model tends to overestimate the vertical gradient. PAN: $\mathrm{NO}_{\mathrm{x}}$ ratios are well-simulated in the marine boundary layer, providing some support for the modeled ocean source. We introduce the Model of Emissions of Gases
\end{abstract}

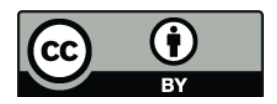

Correspondence to: D. B. Millet (dbm@umn.edu) and Aerosols from Nature (MEGANv2.1) for acetaldehyde and ethanol and use it to quantify their net flux from living terrestrial plants. Including emissions from decaying plants the total direct acetaldehyde source from the land biosphere is $23 \mathrm{Tg} \mathrm{a}^{-1}$. Other terrestrial acetaldehyde sources include biomass burning $\left(3 \mathrm{Tg} \mathrm{a}^{-1}\right)$ and anthropogenic emissions $\left(2 \mathrm{Tg} \mathrm{a}^{-1}\right)$. Simulated concentrations in the continental boundary layer are generally unbiased and capture the spatial gradients seen in observations over North America, Europe, and tropical South America. However, the model underestimates acetaldehyde levels in urban outflow, suggesting a missing source in polluted air. Ubiquitous high measured concentrations in the free troposphere are not captured by the model, and based on present understanding are not consistent with concurrent measurements of PAN and $\mathrm{NO}_{\mathrm{x}}$ : we find no compelling evidence for a widespread missing acetaldehyde source in the free troposphere. We estimate the current US source of ethanol and acetaldehyde (primary + secondary) at $1.3 \mathrm{Tg} \mathrm{a}^{-1}$ and $7.8 \mathrm{Tg} \mathrm{a}^{-1}$, approximately $60 \%$ and $480 \%$ of the corresponding increases expected for a national transition from gasoline to ethanol fuel.

\section{Introduction and background}

Acetaldehyde $\left(\mathrm{CH}_{3} \mathrm{CHO}\right)$ plays an important role in the atmosphere as a source of ozone $\left(\mathrm{O}_{3}\right)$, peroxyacetyl nitrate (PAN) (Roberts, 1990) and $\mathrm{HO}_{\mathrm{x}}$ radicals (Singh et al., 1995),

Published by Copernicus Publications on behalf of the European Geosciences Union. 
and is classified as a hazardous air pollutant by the US EPA (EPA, 1994). Sources of atmospheric acetaldehyde, which include photochemical production as well as direct anthropogenic and natural emissions, are poorly understood (Singh et al., 2004). Here we present the first focused 3-D model analysis of the global acetaldehyde budget, and interpret recent aircraft and surface measurements in terms of their implications for current understanding of acetaldehyde sources and sinks.

The largest source of atmospheric acetaldehyde is thought to be photochemical degradation of volatile organic compounds (VOCs) such as >C1 alkanes and >C2 alkenes (Atkinson et al., 2006). We also examine here to what extent oxidation of isoprene $\left(\mathrm{C}_{5} \mathrm{H}_{8}\right)$ and ethanol $\left(\mathrm{C}_{2} \mathrm{H}_{5} \mathrm{OH}\right)$ contributes to the acetaldehyde budget. Ethanol is of particular interest as a renewable alternative to fossil fuel. Since ethanol combustion emissions consist largely of unburned ethanol itself (Black, 1991; Jacobson, 2007) which is subsequently oxidized to acetaldehyde, quantifying existing acetaldehyde sources is key for predicting air quality outcomes of increased ethanol fuel use (Hill et al., 2006, 2009; Jacobson, 2007). Later we will gauge the projected acetaldehyde increase for a US transition to ethanol fuel in relation to its current sources.

In addition to photochemical production, acetaldehyde is emitted directly to the atmosphere by terrestrial plants, as a result of fermentation reactions leading to ethanol production in leaves and roots (Kreuzwieser et al., 1999; Fall, 2003; Cojocariu et al., 2004; Jardine et al., 2008; Rottenberger et al., 2008; Winters et al., 2009). Within leaves, acetaldehyde can also be enzymatically oxidized to acetate and metabolically consumed (Fall, 2003), and as a result exchange with the atmosphere is bi-directional, with the net flux determined by temperature and light levels, by the ambient acetaldehyde concentration, and by stomatal conductance (Kesselmeier, 2001; Schade and Goldstein, 2001; Jardine et al., 2008; Winters et al., 2009). It will be shown in this study that biogenic emissions are the dominant direct terrestrial source of atmospheric acetaldehyde, but are small relative to secondary photochemical production.

Direct emissions of acetaldehyde also occur during urban and industrial activities, mainly as a by-product of combustion (EPA, 2007; Ban-Weiss et al., 2008; Zavala et al., 2009), and from its production and use as a chemical intermediate (EPA, 1994). Other direct sources of atmospheric acetaldehyde include biomass and biofuel burning (Holzinger et al., 1999; Zhang and Smith, 1999; Andreae and Merlet, 2001; Christian et al., 2003; Greenberg et al., 2006; Karl et al., 2007; Yokelson et al., 2008) and decaying plant matter (Kirstine et al., 1998; de Gouw et al., 1999; Warneke et al., 1999; Schade and Goldstein, 2001; Karl et al., 2005b).

Acetaldehyde is produced in surface waters from photodegradation of colored dissolved organic matter (Kieber et al., 1990; Zhou and Mopper, 1997), and subsequently emitted to the atmosphere (Singh et al., 2003; Sinha et al., 2007;
Colomb et al., 2009). Singh et al. (2001, 2004) suggested that high acetaldehyde concentrations measured over the Pacific during the TRACE-P and PEM-Tropics B aircraft missions might be explained by a large ocean source. However, the likelihood of this is unclear, since the TRACE-P and PEMTropics B measurements above the marine boundary layer (MBL) appear inconsistent with concurrent measurements of PAN and $\mathrm{NO}_{\mathrm{x}}\left(\mathrm{NO}_{\mathrm{x}} \equiv \mathrm{NO}+\mathrm{NO}_{2}\right)$ (Staudt et al., 2003; Singh et al., 2004), and it is suspected that acetaldehyde can be produced artificially on Teflon inlet tubing (Northway et al., 2004). As a result, it is not known whether oceanic emissions are an important source of atmospheric acetaldehyde, or even whether the global ocean is a net source or sink. Here we present new constraints on this problem using satellite data, and infer that the ocean is a significant net source of atmospheric acetaldehyde.

The principal sink of atmospheric acetaldehyde appears to be reaction with $\mathrm{OH}$, giving an atmospheric lifetime on the order of one day (Atkinson et al., 2006). Other sinks include photolysis (Sander et al., 2006) and wet and dry deposition (Warneke et al., 2002; Karl et al., 2004; Custer and Schade, 2007).

In this paper we use a 3-D chemical transport model (GEOS-Chem CTM) to develop the first detailed global budget for atmospheric acetaldehyde, and use atmospheric observations to test the model representation of sources and sinks. Detailed studies of acetaldehyde measurement artifacts by Northway et al. (2004) and Apel et al. (2003), and a large-scale blind intercomparison study by Apel et al. (2008), concluded that measurement artifacts for this compound generally manifest as a background problem most significant in clean background air. For that reason, we focus our comparisons mainly on the continental boundary layer and continental outflow, where measured concentrations are elevated and correlate well with other continental tracers. We also evaluate the model-measurement comparisons in terms of consistency with other chemical measurements $\left(\mathrm{PAN}, \mathrm{NO}_{\mathrm{x}}\right)$ and current mechanistic understanding.

\section{Model description}

\subsection{Framework}

We use the GEOS-Chem global 3-D CTM to simulate the atmospheric distribution of acetaldehyde and related tracers for 2004 (Bey et al., 2001; Millet et al., 2009). GEOS-Chem (version 8, http://www.geos-chem.org) uses GEOS-5 assimilated meteorological data from the NASA Goddard Earth Observing System including winds, convective mass fluxes, mixing depths, temperature, precipitation, and surface properties. The data have 6-h temporal resolution (3-h for surface variables and mixing depths), $0.5^{\circ} \times 0.667^{\circ}$ horizontal resolution, and 72 vertical layers. For computational expediency we degrade the horizontal resolution to $2^{\circ} \times 2.5^{\circ}$ 

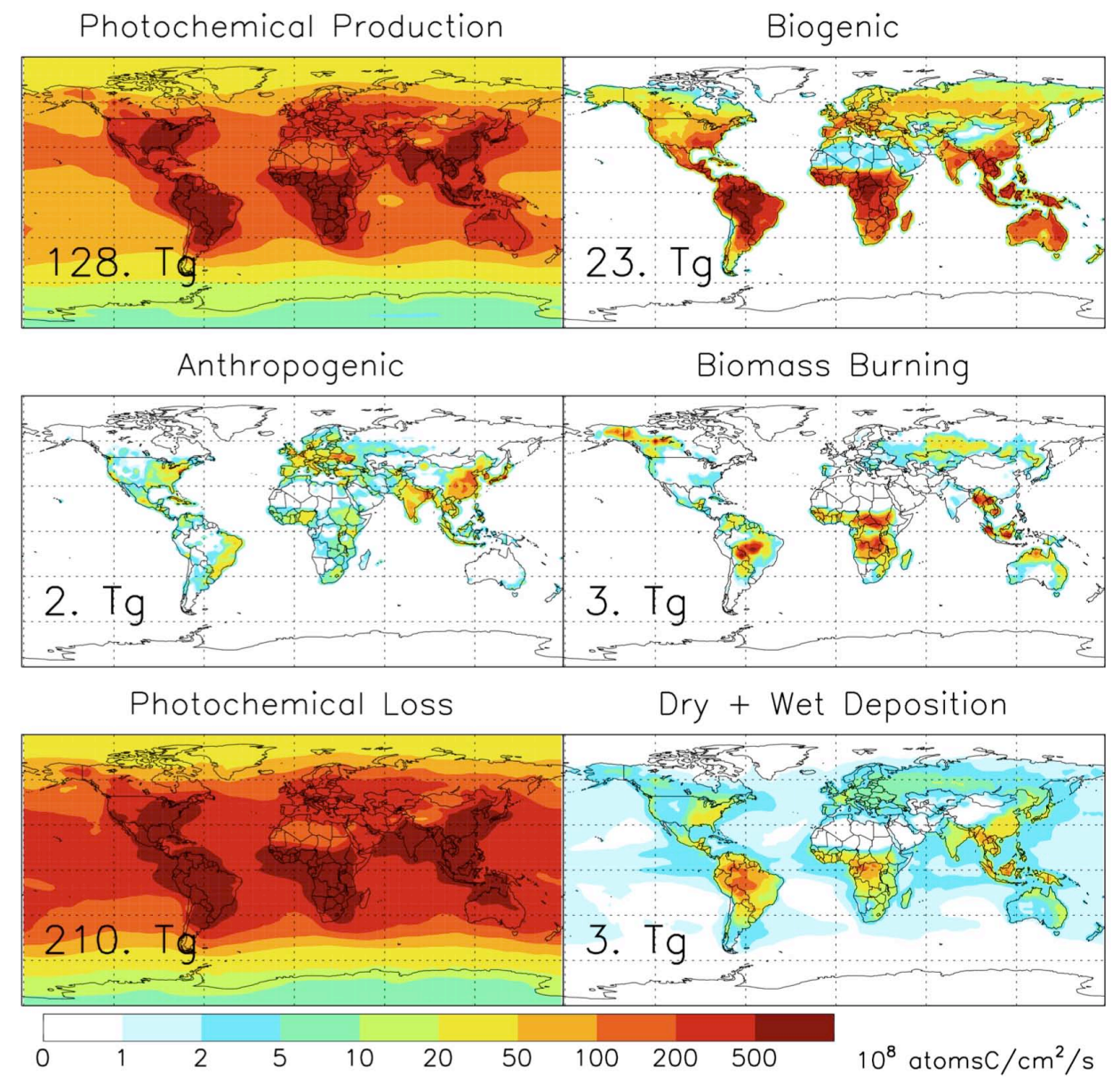

Fig. 1. Annual average sources and sinks of acetaldehyde in GEOS-Chem. Shown are photochemical production, biogenic emissions from live and decaying plants, anthropogenic emissions (urban/industrial + biofuel), biomass burning emissions, photochemical loss $(\mathrm{OH}+$ photolysis $)$, and deposition. Net ocean exchange is shown separately in Fig. 6.

and the vertical resolution to 47 vertical layers, of which 14 are below $2 \mathrm{~km}$ altitude. Results are shown following a 1year spinup to remove the effects of initial conditions. The model includes detailed ozone- $\mathrm{NO}_{\mathrm{x}}-\mathrm{VOC}$ chemistry coupled to aerosols, with 120 species simulated explicitly.

The standard GEOS-Chem simulation only includes photochemical sources and sinks for acetaldehyde. For this work, the model has been modified to include direct continental and marine emissions, wet and dry deposition, and air-sea exchange of acetaldehyde. Global distributions of the annual average sources and sinks for atmospheric acetaldehyde are shown in Figs. 1 and 6 and discussed in detail in the following sections.

Due to its importance as an acetaldehyde precursor, we have also expanded the GEOS-Chem model to include atmospheric ethanol. The ethanol simulation includes emissions from living terrestrial plants (global flux $17 \mathrm{Tg} \mathrm{a}^{-1}$ ) calculated using MEGANv2.1 (see below), as well as anthropogenic $\left(2 \mathrm{Tg} \mathrm{a}^{-1}\right)$, plant decay $\left(6 \mathrm{Tg} \mathrm{a}^{-1}\right)$ and biomass burning $\left(0.07 \mathrm{Tg} \mathrm{a}^{-1}\right)$ emissions calculated as described be- low for acetaldehyde. There is also a small photochemical source $\left(0.3 \mathrm{Tg} \mathrm{a}^{-1}\right)$ of ethanol from permutation reactions of organic peroxy radicals (Madronich and Calvert, 1990; Tyndall et al., 2001). Sinks of atmospheric ethanol include reaction with $\mathrm{OH}(77 \%)$ and wet/dry deposition (23\%), leading to an overall atmospheric lifetime of 3.7 days. Figure 2 shows the global distribution of the modeled ethanol sources and sinks.

Initial GEOS-Chem simulations revealed excessive acetaldehyde production from isoprene oxidation, with simulated yields 3-6x higher than the Master Chemical Mechanism version 3.1 (MCMv3.1; Bloss et al., 2005). As part of this work we have made extensive updates to the GEOS-Chem chemical mechanism according to the most recent available recommendations (e.g., Atkinson et al., 2006; Sander et al., 2006). These updates have now been incorporated into the standard GEOS-Chem model beginning with version 8.02.01. 


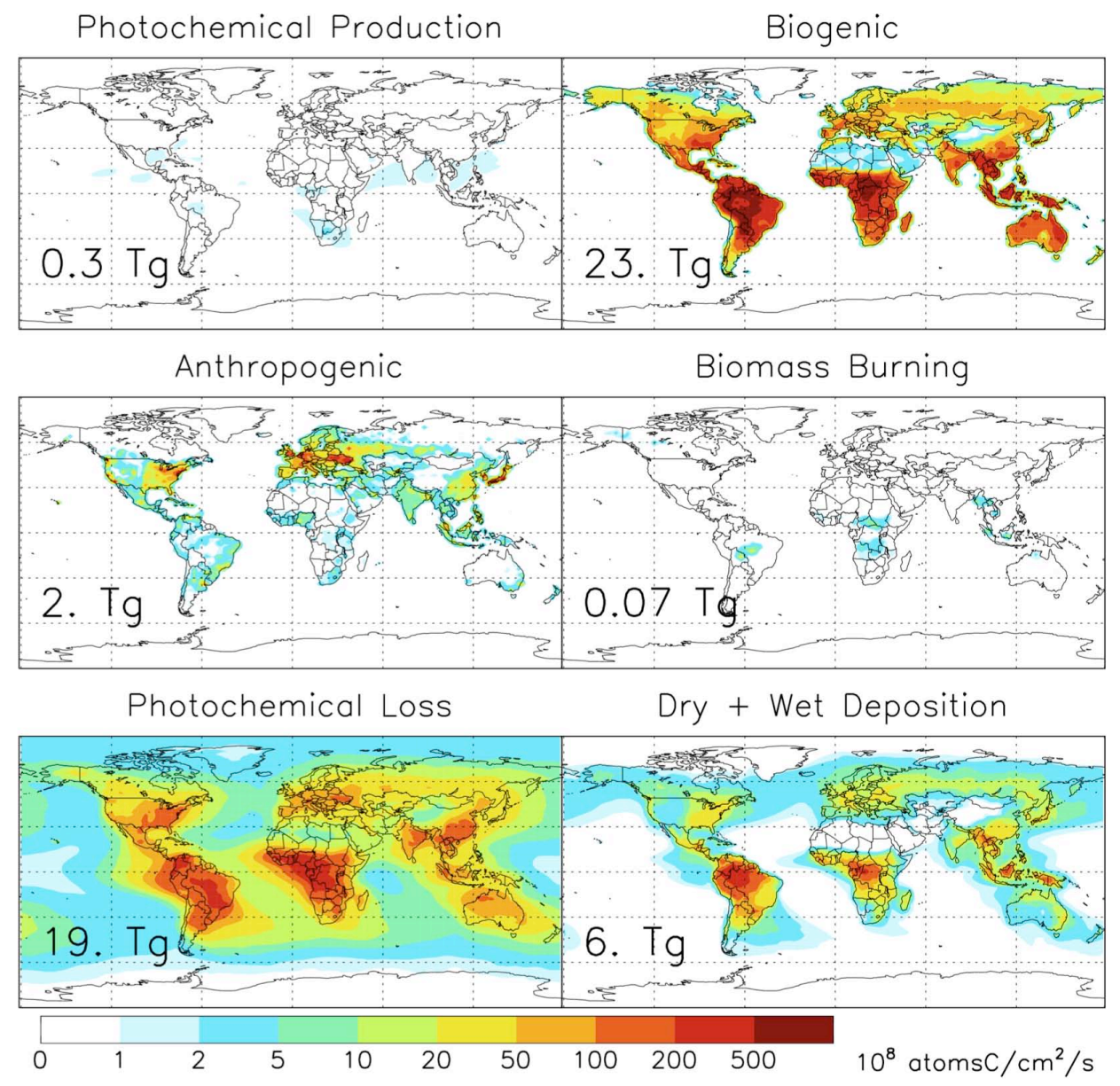

Fig. 2. Annual average sources and sinks of ethanol in GEOS-Chem. Shown are photochemical production, biogenic emissions from live and decaying plants, anthropogenic emissions (urban/industrial + biofuel), biomass burning emissions, photochemical loss, and deposition.

\subsection{Photochemical production of acetaldehyde}

Figure 1 shows the total photochemical production of acetaldehyde for a full-chemistry, global GEOS-Chem simulation, which totals $128 \mathrm{Tg} \mathrm{a}^{-1}$ and is the dominant source term in the overall budget. In this section we use the box model framework described by Emmerson and Evans (2009) to evaluate the GEOS-Chem acetaldehyde production yields for individual precursors in relation to those from MCMv3.1, and estimate the importance of each for global acetaldehyde production. Later we will evaluate the photochemical production of acetaldehyde in GEOS-Chem against aircraft and surface measurements.

Figure 3 and Table 1 show cumulative acetaldehyde yields for the most important precursors, calculated using GEOSChem (updated for this work as described in Sect. 2.1) and MCMv3.1. The box-model runs are initiated at 00:00 local time for midlatitude summertime conditions with $1 \mathrm{ppb}$ of the precursor VOC, $40 \mathrm{ppb} \mathrm{O}_{3}, 100 \mathrm{ppb} \mathrm{CO}, 1.7 \mathrm{ppm}$ methane, $2 \% \mathrm{H}_{2} \mathrm{O}(\mathrm{v} / \mathrm{v})$, and either 0.1 or $1 \mathrm{ppb}$ of $\mathrm{NO}_{\mathrm{x}}$ (taken to represent low and high $\mathrm{NO}_{\mathrm{x}}$ regimes). For these box-model runs, $\mathrm{NO}_{\mathrm{x}}$ and ozone are maintained at their initial concentrations while the precursor VOC is allowed to decay over ten diel cycles (only the first two days are shown in Fig. 3). For each precursor class below, we provide an estimated range for the total contribution to acetaldehyde production based on the product (global emissions) $\times$ (GEOSChem box-model acetaldehyde yield) (Fig. 4).

\subsubsection{Alkanes and alkenes}

Acetaldehyde is generally produced from the photooxidation of >C1 alkanes and >C2 alkenes (Altshuller, 1991a, b). Figure 3 shows molar yields from the three most abundant atmospheric alkanes (ethane, propane, and n-butane) plus propene. As we see, yields computed with GEOS-Chem are in general agreement with MCMv3.1. Computed 10-day molar yields for these alkanes are listed in Table 1 and range from $23-107 \%$ depending on the VOC and on $\mathrm{NO}_{\mathrm{x}}$ level, with calculated yields higher in all cases at high $\mathrm{NO}_{\mathrm{x}}$. For ethane and propane, the 10-day GEOS-Chem and MCMv3.1 yields agree to within $15 \%$. GEOS-Chem uses a lumped 


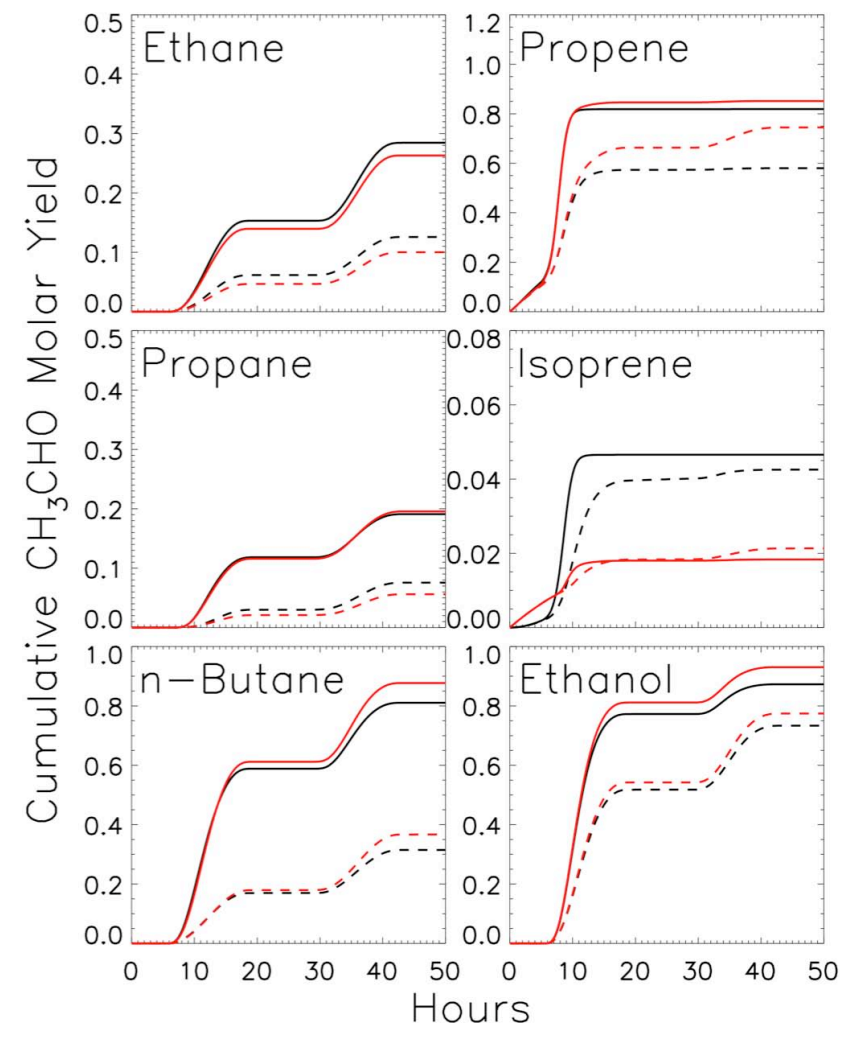

Fig. 3. Cumulative molar yield of acetaldehyde from the oxidation of VOCs. Yields are computed using the GEOS-Chem (red) and MCMv3.1 (black) chemical mechanisms, for $1 \mathrm{ppb} \mathrm{NO}$ (solid lines) and $0.1 \mathrm{ppb} \mathrm{NO}_{\mathrm{x}}$ (dashed lines).

species to represent $\geq \mathrm{C} 4$ alkanes, which has acetaldehyde yields within $25 \%$ of those for n-butane in MCMv3.1. GEOS-Chem also uses a lumped species to represent $\geq \mathrm{C} 3$ alkenes other than isoprene; in this case the GEOS-Chem yields fall between the corresponding MCMv3.1 values for propene and 1-butene.

Figure 4 shows the estimated contribution of alkanes and alkenes to global acetaldehyde production, calculated based on their total emissions and their high- $\mathrm{NO}_{\mathrm{x}}$ and low- $\mathrm{NO}_{\mathrm{x}}$ yields from the box-model simulations. We estimate that emissions of alkanes and alkenes, excluding isoprene, result in 77-96 $\mathrm{Tg} \mathrm{a}^{-1}$ of secondary acetaldehyde production (the range reflects the differing yields at high and low- $\mathrm{NO}_{\mathrm{x}}$ ).

\subsubsection{Isoprene}

Production of acetaldehyde during isoprene oxidation occurs from photolysis of methyl vinyl ketone (MVK) (Atkinson et al., 2006) and ozonolysis of isoprene (Paulson et al., 1992; Grosjean et al., 1993; Taraborrelli et al., 2009). Both routes involve the production of propene, which then degrades to acetaldehyde. GEOS-Chem and MCMv3.1 also include a minor acetaldehyde source from ozonolysis of MVK, with a molar yield of $4 \%$ (GEOS-Chem) and $10 \%$
Table 1. Molar Yields of Acetaldehyde for its Dominant Precursors $^{\mathrm{a}}$.

\begin{tabular}{lllll}
\hline Species & \multicolumn{2}{c}{$1 \mathrm{ppb} \mathrm{NO}_{\mathrm{x}}$} & \multicolumn{2}{c}{$0.1 \mathrm{ppb} \mathrm{NO}$} \\
\hline & GEOS-Chem & MCMv3.1 & GEOS-Chem & MCMv3.1 \\
Ethane & 0.78 & 0.81 & 0.48 & 0.52 \\
Propane & 0.30 & 0.26 & 0.23 & 0.24 \\
n-Butane & - & 0.98 & - & 0.69 \\
ALK4 $^{\mathrm{b}}$ & 1.07 & - & 0.91 & - \\
Propene & - & 0.82 & - & 0.58 \\
PRPE & 0.85 & - & 0.83 & - \\
1-Butene $^{\mathrm{C}}$ & - & 0.99 & - & 0.97 \\
Isoprene & 0.019 & 0.047 & 0.025 & 0.043 \\
Ethanol & 0.95 & 0.89 & 0.95 & 0.89 \\
\hline
\end{tabular}

a 10-day yields calculated using GEOS-Chem and MCMv3.1 box-model runs as described in Sect. 2.

${ }^{\mathrm{b}}$ GEOS-Chem lumped species for $\geq \mathrm{C} 4$ alkanes.

${ }^{c}$ GEOS-Chem lumped species for $\geq \mathrm{C} 3$ alkenes.

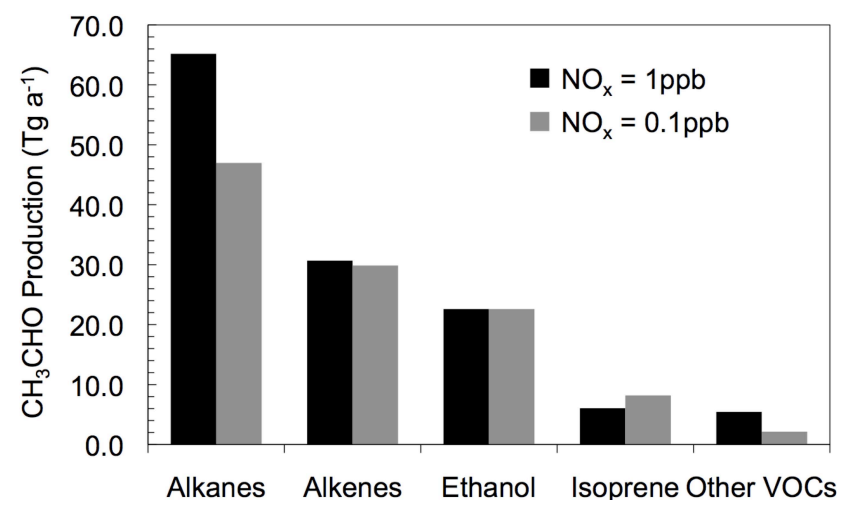

Fig. 4. Contribution of VOC precursors to global acetaldehyde production calculated using the GEOS-Chem high- $\mathrm{NO}_{\mathrm{x}}$ and low- $-\mathrm{NO}_{\mathrm{x}}$ 10-day yields.

(MCMv3.1). The initial product of this reaction is a primary ozonide which decomposes to methylglyoxal $+\left[\mathrm{CH}_{2} \mathrm{OO}\right]^{*}$ or to formaldehyde $+\left[\mathrm{CH}_{3} \mathrm{C}(\mathrm{O}) \mathrm{CHOO}\right]^{*}$ (Atkinson et al., 2006). Acetaldehyde production then occurs through degradation of the $\left[\mathrm{CH}_{3} \mathrm{C}(\mathrm{O}) \mathrm{CHOO}\right]^{*}$ biradical. Grosjean et al. (1993) found an average methylglyoxal yield of $87 \%$ for the $\mathrm{MVK}+\mathrm{O}_{3}$ reaction, which, given that $\left[\mathrm{CH}_{3} \mathrm{C}(\mathrm{O}) \mathrm{CHOO}\right]^{*}$ will also produce some methylglyoxal ( 24\%; Bloss et al., 2005), implies a $\sim 17 \%$ yield for the formaldehyde $+\left[\mathrm{CH}_{3} \mathrm{C}(\mathrm{O}) \mathrm{CHOO}\right]^{*}$ pathway. Assuming $\left[\mathrm{CH}_{3} \mathrm{C}(\mathrm{O}) \mathrm{CHOO}\right]^{*}$ decomposes to acetaldehyde with $20 \%$ efficiency (Bloss et al., 2005), this then implies an overall acetaldehyde yield from $\mathrm{MVK}+\mathrm{O}_{3}$ of $3.4 \%$ - similar to the $4 \%$ used in GEOS-Chem.

In all the above cases acetaldehyde is produced as a second- or higher-generation oxidation product of isoprene. Figure 3 shows that the resulting molar yield is small, but owing to the large global isoprene flux it results in a non-negligible source of atmospheric acetaldehyde. The 
10-day acetaldehyde yields computed using GEOS-Chem are $1.9 \%\left(\right.$ high- $-\mathrm{NO}_{\mathrm{x}}$ ) and $2.5 \%$ (low- $\mathrm{NO}_{\mathrm{x}}$ ), compared to $4.7 \%$ and $4.3 \%$ for MCMv3.1 (Table 1). For comparison, Lee et al. (2006) measured a $1.9 \pm 0.3 \%$ acetaldehyde yield from isoprene oxidation under high- $\mathrm{NO}_{\mathrm{x}}$ conditions, in good agreement with GEOS-Chem. Using the Mainz Isoprene Mechanism 2 (MIM2) in a 3-D atmospheric model, Taraborrelli et al. (2009) estimate a global, annual average acetaldehyde yield from isoprene oxidation of $2 \%$, also consistent with the GEOS-Chem box-model values.

Figure 4 shows the total amount of acetaldehyde produced from isoprene oxidation, estimated as the product of global isoprene emissions and the GEOS-Chem box-model acetaldehyde yields: $6 \mathrm{Tg} \mathrm{a}^{-1}$ based on the high- $\mathrm{NO}_{\mathrm{x}}$ yield and $8 \mathrm{Tg} \mathrm{a}^{-1}$ based on the low- $\mathrm{NO}_{\mathrm{x}}$ yield.

\subsubsection{Ethanol}

Ethanol oxidation produces acetaldehyde nearly quantitatively: 10-day molar yields are 95\% for GEOS-Chem and $89 \%$ for MCMv3.1, and are not sensitive to $\mathrm{NO}_{\mathrm{x}}$ (Table 1). As shown in Fig. 4, we estimate that global emissions of ethanol, which are predominantly biogenic, result in $23 \mathrm{Tg} \mathrm{a}^{-1}$ of secondary acetaldehyde production. In Sect. 5 we will evaluate these sources in relation to that predicted from increased use of ethanol fuel in the US.

\subsection{Terrestrial sources of acetaldehyde}

\subsubsection{Biogenic emissions and MEGANv2.1 model description}

Acetaldehyde production in plants appears to be mainly due to alcoholic fermentation in leaves and roots, with emissions representing a "leak in the pipe" between endpoints of ethanol production and acetate consumption (Kesselmeier, 2001; Schnitzler et al., 2002; Rottenberger et al., 2004; Karl et al., 2005a; Filella et al., 2009; Winters et al., 2009). Acetaldehyde emissions are strongly temperature and lightdependent, and can be stimulated by light-dark transitions, leading to speculation that sunflecks in the lower canopy could lead to high emission rates (Karl et al., 2002; Fall, 2003). However, subsequent work has concluded that sunflecks do not significantly enhance emission rates in the field (Grabmer et al., 2006), and in fact that leaf emission capacity increases strongly with light and temperature, so the sunlit upper canopy tends to act as a net acetaldehyde source and the lower shaded leaves as a net sink (Karl et al., 2004; Jardine et al., 2008).

Acetaldehyde emission from plants is enhanced by anoxic conditions, for example in roots when the soil is flooded or in other tissues subjected to stress (Kimmerer and Kozlowski, 1982; Kimmerer and Macdonald, 1987; Kreuzwieser et al., 2004; Cojocariu et al., 2005; Rottenberger et al., 2008). However, emissions also occur as a part of normal (non- stressed) plant functioning, perhaps due to oxidation of ethanol generally present in the xylem, or to fermentation within the leaf itself (Schade and Goldstein, 2001; Karl et al., 2003; Cojocariu et al., 2004; Jardine et al., 2008; Winters et al., 2009). Kimmerer and Kozlowski (1982) measured enhanced emissions from drought-stressed plants, but this did not occur until well past the wilting point and was associated with physical lesions and plant damage. Other work has not shown a clear influence of drought conditions on acetaldehyde emissions (Schade and Goldstein, 2002; Filella et al., 2009).

Here, we introduce the MEGANv2.1 algorithms for estimating acetaldehyde (and ethanol) emissions from terrestrial plants. Specific parameter values and a description of the datasets used to derive them are given in the Supplemental Information. Below we will use MEGANv2.1 in GEOSChem to compute global biogenic emissions of acetaldehyde, ethanol, and other VOCs, and as a base-case for evaluation. MEGANv2.1 computes VOC emissions as a function of temperature, photosynthetically active radiation (PAR), leaf area index (LAI), and leaf age for plant functional types (PFTs): broadleaf trees, fineleaf trees, shrubs, crops, and grasses. Emissions from a GEOS-Chem grid cell are computed as:

$E=\gamma \sum_{i=1}^{5} \varepsilon_{i} \chi_{i}$,

where the sum is over the five PFTs with fractional coverage $\chi_{i}$ and local canopy emission factor $\varepsilon_{i}$ under standard environmental conditions (Guenther et al., 2006). Figure S1 (http://www.atmos-chem-phys.net/10/ 3405/2010/acp-10-3405-2010-supplement.pdf) shows the global MEGANv2.1 emission factor distribution for acetaldehyde and ethanol. The effect of variability in temperature, PAR, LAI, soil moisture and leaf age on emissions is accounted for by the emission activity factor $\gamma$, defined in terms of a set of non-dimensional activity factors:

$\gamma=\gamma_{T} \gamma_{\mathrm{LAI}} \gamma_{\mathrm{SM}} \gamma_{\mathrm{age}}\left[(1-\mathrm{LDF})+(\mathrm{LDF}) \gamma_{P}\right]$

where the individual activity factors are each equal to one under standard conditions (Guenther et al., 1999, 2006). The parameter LDF reflects the light-dependent fraction of emissions. For non-isoprene VOCs, MEGANv2.1 models the temperature response as

$\gamma_{T}=\exp [\beta(T-303)]$,

with $\beta$ defining the temperature sensitivity for a particular compound. For isoprene, $\gamma_{T}$ is computed as a function both of the current temperature and the average temperature over the previous 10 days following Guenther et al. (2006). The LAI activity factor $\gamma_{\text {LAI }}$ accounts for the bidirectional flux of acetaldehyde and ethanol, with net emission from sunlit leaves and net uptake from shaded leaves:

$\gamma_{\mathrm{LAI}}=0.5 \cdot \mathrm{LAI}($ for $\mathrm{LAI} \leq 2)$ 
$\gamma_{\mathrm{LAI}}=1-0.0625(\mathrm{LAI}-2)($ for $2<\mathrm{LAI} \leq 6)$

$\gamma_{\text {LAI }}=0.75$ (for $\mathrm{LAI}>6$ )

The PAR activity factor $\gamma_{P}$ (as well as $\gamma_{\text {LAI }}$ for other compounds) is calculated using the PCEEA algorithm described by Guenther et al. (2006). In the case of isoprene, we explicitly consider the effect of leaf age on emissions following Guenther et al. (2006). There is conflicting evidence regarding a leaf age dependence for acetaldehyde emissions (Karl et al., 2005a; Rottenberger et al., 2005), and a lack of information for ethanol, and so we do not include a leaf age effect in either case.

The soil moisture activity factor $\gamma_{\mathrm{SM}}$ accounts for the effect of root flooding on acetaldehyde and ethanol emissions. While the functional form of the soil moisture-emission dependence is uncertain (Rottenberger et al., 2008), we make a first attempt to account for flooding-induced enhancements using the GEOS-5 root zone soil saturation parameter (GMAO, 2008), which is the ratio of the volumetric soil moisture to the soil porosity. We set $\gamma_{S M}$ equal to one for root zone saturation ratios below 0.9 , increasing linearly to 3 for a saturation ratio of 1 (Holzinger et al., 2000; Kreuzwieser et al., 2000; Rottenberger et al., 2008). Accounting for the effect of soil moisture in this way increases the modeled annual source from living plants by $10 \%$ globally, though local enhancements can reach $100 \%$ or more.

We drive MEGANv2.1 in GEOS-Chem with GEOS-5 assimilated surface air temperature and direct and diffuse PAR, and with monthly mean LAI values based on MODIS Collection 5 satellite data (Yang et al., 2006). We obtain the average LAI for vegetated areas by dividing the grid-cell average LAI by the fractional vegetation coverage. Fractional coverage $\chi_{i}$ for each PFT and vegetation-specific emission factors $\varepsilon_{i}$ are based on the MEGAN land cover data (PFT v2.1, EFs v2.1). In our previous work we showed that the MEGAN land cover gives predicted North American isoprene fluxes that are spatially well-correlated with space-borne formaldehyde measurements (Millet et al., 2008a), providing some confidence in the reliability of this product.

Acetaldehyde is also emitted from dead and decaying plant matter, with measured emissions ranging from $3-80 \times 10^{-6}$ on a mass basis relative to plant dry weight (de Gouw et al., 2000; Karl et al., 2001a, b, 2005b; Warneke et al., 2002). Here we apply a value of $40 \times 10^{-6}$ to global fields of heterotrophic respiration from the CASA 2 model (Randerson, 1997), following earlier work for methanol (Jacob et al., 2005; Millet et al., 2008b), which yields a global acetaldehyde source of $6 \mathrm{Tg} \mathrm{a}^{-1}$. Combined with the living plant emissions $\left(17 \mathrm{Tg} \mathrm{a}^{-1}\right)$, the total modeled acetaldehyde source from terrestrial vegetation is then $23 \mathrm{Tg} \mathrm{a}^{-1}$, as shown in Fig. 1.

\subsubsection{Anthropogenic emissions}

We estimate direct anthropogenic emissions (excluding biofuel and biomass burning) of acetaldehyde and ethanol in GEOS-Chem based on the POET inventory (Olivier et al., 2003; Granier, 2005). POET provides unspeciated emission estimates for $>\mathrm{C} 1$ aldehydes and alcohols, and we assume here that acetaldehyde and ethanol account for $75 \%$ of these respective categories (EPA, 2007). Global emissions from biofuel use are estimated using the gridded climatological CO emission inventory from Yevich and Logan (2003) and recommended species emission ratios relative to $\mathrm{CO}$ from Andreae and Merlet (2001) and Andreae (unpublished data, 2006).

Global anthropogenic emissions for other compounds are as described by Bey et al. (2001) for VOCs and $\mathrm{NO}_{\mathrm{x}}$ and Duncan et al. (2007) for CO, except as follows. Emissions for the US are based on the US EPA inventory for 1999 (NEI99), accounting for recent $\mathrm{CO}$ and $\mathrm{NO}_{\mathrm{x}}$ reductions (Hudman et al., 2007; Hudman et al., 2008). US ethane and propane emissions are scaled up by a factor of 3.5 from the NEI99 based on the work of Xiao et al. (2008) and Warneke et al. (2007). Emissions for Asia and Europe are based on Zhang et al. (2009) and EMEP (Vestreng and Klein, 2002), respectively. Emissions of $\mathrm{CO}$ and $\mathrm{NO}_{\mathrm{x}}$ for northern Mexico and for Canada are from BRAVO (Kuhns et al., 2005) and the Environment Canada inventory (http://www.ec.gc. ca/inrp-npri/) for 2005. In all cases emissions are scaled to the simulation year using national statistics for liquid fuel $\mathrm{CO}_{2}$ emissions. Global biofuel emissions are computed in the same way as for acetaldehyde and ethanol.

The resulting flux-weighted mean acetaldehyde: $\mathrm{CO}$ direct anthropogenic emission ratio over the US and Mexico is $3 \times 10^{-3} \mathrm{~mole} / \mathrm{mole}$, consistent with values of $1-$ $4 \times 10^{-3}$ mole/mole derived from atmospheric measurements during the NEAQS-2K2, ITCT-2K4, and MILAGRO field campaigns (de Gouw et al., 2005; Warneke et al., 2007; de Gouw et al., 2009). Figure 1 shows the global distribution of the modeled anthropogenic acetaldehyde source, which totals $2 \operatorname{Tg} \mathrm{a}^{1}$.

\subsubsection{Biomass burning}

Biomass burning emissions are estimated based on a global $\mathrm{CO}$ emission inventory with monthly resolution from the Global Fire Emissions Database version 2 (GFEDv2) (Randerson et al., 2006; van der Werf et al., 2006), with emission factors relative to CO from Andreae and Merlet (2001) and Andreae (unpublished data, 2006). These emission factors range from $7.9-9.2 \times 10^{-3} \mathrm{~g} / \mathrm{g}$, and the resulting global source of acetaldehyde is $3 \mathrm{Tg} \mathrm{a}^{-1}$ (Fig. 1). 


\subsection{Air-sea exchange}

Acetaldehyde is produced in natural waters through photodegradation of colored dissolved organic matter (CDOM). Kieber et al. (1990) carried out experiments exposing a range of natural waters to sunlight, and found a strong correlation $\left(R^{2}=0.98\right)$ between the acetaldehyde production rate and absorbance at $300 \mathrm{~nm}$, reflecting the CDOM content of the water sample. The yield of $90 \cdot a_{\mathrm{cdom}}[300] \cdot d$, in units of $\mathrm{nM} /\left(\mathrm{W} \cdot \mathrm{h} \cdot \mathrm{m}^{-2}\right)$ with $a_{\text {cdom }}[300]$ the absorption coefficient of the water $\left(\mathrm{m}^{-1}\right)$ and $d$ the path length (m), appeared consistent across coastal, open ocean, and freshwater samples, and for natural water samples as well as those with added humic extracts. Here we present a new approach to quantifying the global air-sea acetaldehyde flux using this measured production rate and oceanic CDOM fields derived from satellite data.

We derive global oceanic CDOM absorption at $300 \mathrm{~nm}$, $a_{\text {cdom }}$ [300], from monthly fields of colored dissolved and detrital organic matter (CDM). CDM includes both detrital particulate and dissolved organic matter absorption; these are typically combined in satellite ocean color retrievals as the two factors cannot be differentiated on the basis of their absorption spectra alone (e.g., Maritorena et al., 2002). However, detrital particulate absorption is a minor contributor to CDM (Siegel et al., 2002). Values of CDM are obtained from satellite observations of water-leaving radiance spectra from the Sea-viewing Wide Field-of-view Sensor (SeaWiFS) mission using the Garver-Siegel-Maritorena (GSM) ocean color model (Maritorena et al., 2002; Siegel et al., 2002, 2005). CDM is defined in the GSM model as the absorption coefficient due to colored dissolved and detrital organic matter at $443 \mathrm{~nm}$. Global comparisons of the satellite-retrieved CDM observations with contemporaneous field observations are generally good $\left(R^{2}=0.62\right.$, slope $=1.146, N=112$; $($ Siegel et al., 2005)).

Values of $a_{\mathrm{cdom}}[300]$ are estimated using a linear regression between field observations of the CDOM absorption coefficient at $325 \mathrm{~nm}\left(a_{\text {cdom }}[325]\right)$ throughout the Pacific Ocean and concurrent satellite retrievals of CDM (Swan et al., 2009), or:

$a_{\mathrm{cdom}}[325]=6.373 \cdot \mathrm{CDM}+0.004$,

with $R^{2}=0.72$. We then apply an exponential model for CDOM spectral changes to derive $a_{\text {cdom }}[300]$ :

$a_{\mathrm{cdom}}[\lambda]=a_{\mathrm{cdom}}[325] \cdot \exp [-S(\lambda-325)]$,

where the spectral slope $S=0.0240 \mathrm{~nm}^{-1}$ is the global mean value for a large ensemble of near-surface observations (data from Nelson et al., 2007 and Swan et al., 2009).

We use a global climatology of ocean mixed layer (OML) depth (Montegut et al., 2004) and assume CDOM to be wellmixed vertically through the OML, since the timescale for its destruction is long relative to that for OML mixing (Nelson et al., 1998; Nelson et al., 2007). Attenuation of UV light with depth through the OML is mainly a function of the CDOM content (Siegel et al., 2002; Zepp, 2002). We model the vertical attenuation of downwelling irradiance at $300 \mathrm{~nm}$ through an analysis of global field observations of spectral light attenuation $\left(K_{d}[\lambda]\right.$, in units of $\left.\mathrm{m}^{-1}\right)$ and the water-leaving radiance spectrum, obtained from the NASA SeaBASS biooptical data archive (http://seabass.gsfc.nasa.gov). The fieldobserved water-leaving radiance spectra are used to retrieve in situ values of CDM using the GSM model, and an empirical model derived to predict $K_{d}[\lambda]$ at 320,340 , and $412 \mathrm{~nm}$ given only CDM. Applied at $300 \mathrm{~nm}$, this model can be expressed as:

$$
\begin{aligned}
& K_{d}[300]=K_{w}[300] \\
& +\left(w_{0} \cdot \mathrm{CDM}+w_{1} \cdot \mathrm{CDM}^{2}\right) \exp [-S S(300-443)] \\
& S S=s_{0}+s_{1} \cdot \mathrm{CDM}+s_{2} \cdot \mathrm{CDM}^{2} .
\end{aligned}
$$

The fit coefficients are $s_{0}=0.0124 \mathrm{~nm}^{-1}$, $s_{1}=-0.0772 \mathrm{~m} \mathrm{~nm}^{-1}, \quad s_{2}=0.5993 \mathrm{~m}^{2} \mathrm{~nm}^{-1}, \quad w_{0}=2.0896$, $w_{1}=-8.3816 \mathrm{~m}$, and $K_{w}[300]=0.0405 \mathrm{~m}^{-1}$, and this model captures $>90 \%$ of the total variance in $K_{d}[\lambda]$ observations at 320,340 , and $412 \mathrm{~nm}\left(R^{2}=0.906\right.$, slope $\left.=1.057, N=1126\right)$. The e-folding depths for $300 \mathrm{~nm}$ light calculated in this way generally range from 0.5 to $22 \mathrm{~m}$ depending on CDOM content.

We then compute the in-situ acetaldehyde photoproduction rate as a function of depth in the OML for each GEOSChem grid square using the local values of $a_{\text {cdom }}$ [300], the incident near-UV solar radiation, and $K_{d}[300]$. Figure 5 shows global acetaldehyde photoproduction rates derived in this way, averaged over the OML and by season. We see the highest oceanic production rates near coastlines and in biologically active regions, corresponding to areas with high CDOM content and seasonal solar irradiance.

The steady-state OML acetaldehyde abundance is the product of the local production rate and the acetaldehyde turnover time. Measured turnover times for acetaldehyde in the near-surface ocean range from $\tau=0.3-12 \mathrm{~h}$ (Mopper and Kieber, 1991; Zhou and Mopper, 1997). Here we use $\tau=0.5$ $\mathrm{h}$ as a conservative assumption still broadly consistent with available observational constraints. The turnover time for acetaldehyde in the OML (and its variability) is one of the main sources of uncertainty in this calculation, along with the fact that the CDOM-dependent photoproduction yield is based on just one dataset (albeit an extensive one). Despite these uncertainties, the approach is a step forward as the first means to estimate the global sea-to-air acetaldehyde flux that is based on the actual processes driving its production in the ocean. The steady-state OML acetaldehyde concentrations we calculate are mostly in the range $1.3-20 \mathrm{nM}(0.1-0.9$ quantiles), consistent with the range of observed values $(1.3-37 \mathrm{nM}$; Mopper and Kieber, 1991; Zhou and Mopper, 1997). 

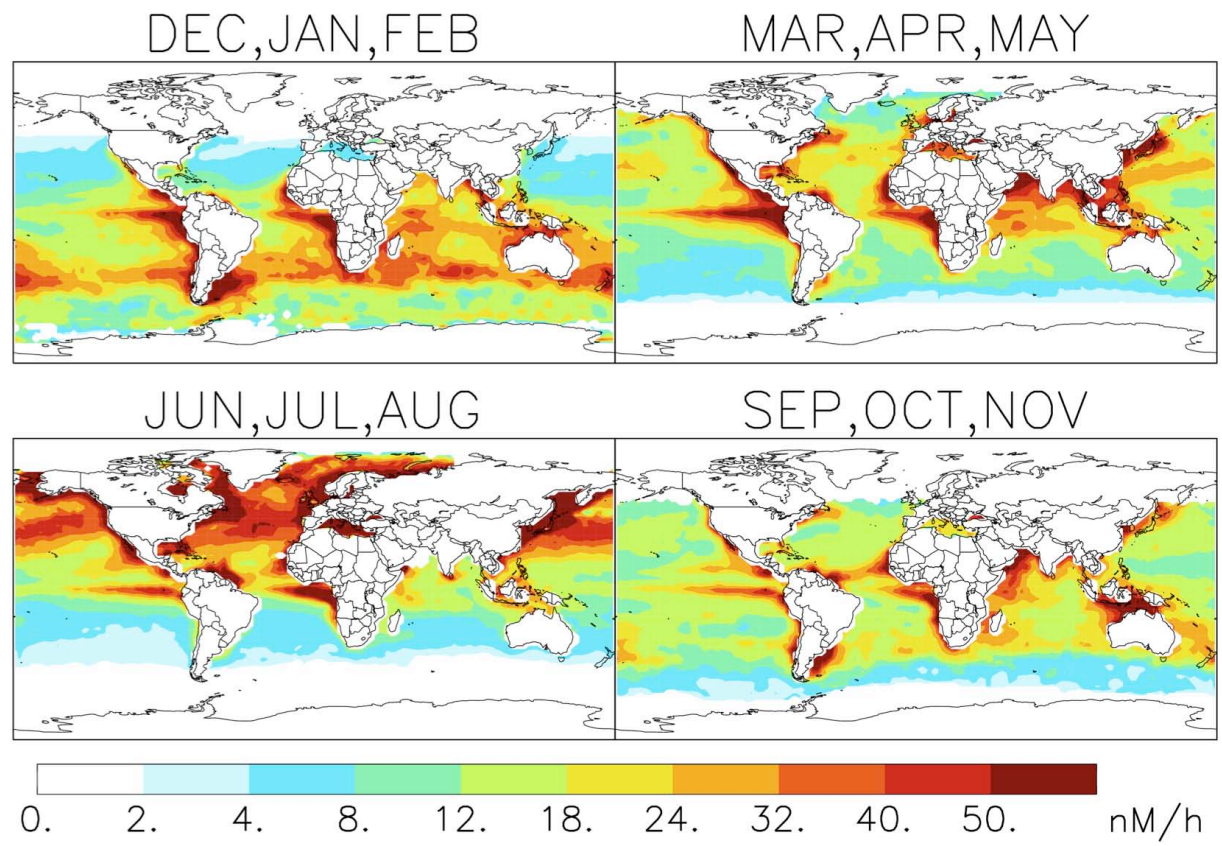

Fig. 5. Acetaldehyde photoproduction in the ocean mixed layer averaged by season. Photoproduction rates are estimated from colored dissolved organic matter absorption fields derived from SeaWiFS satellite observations as described in the text.
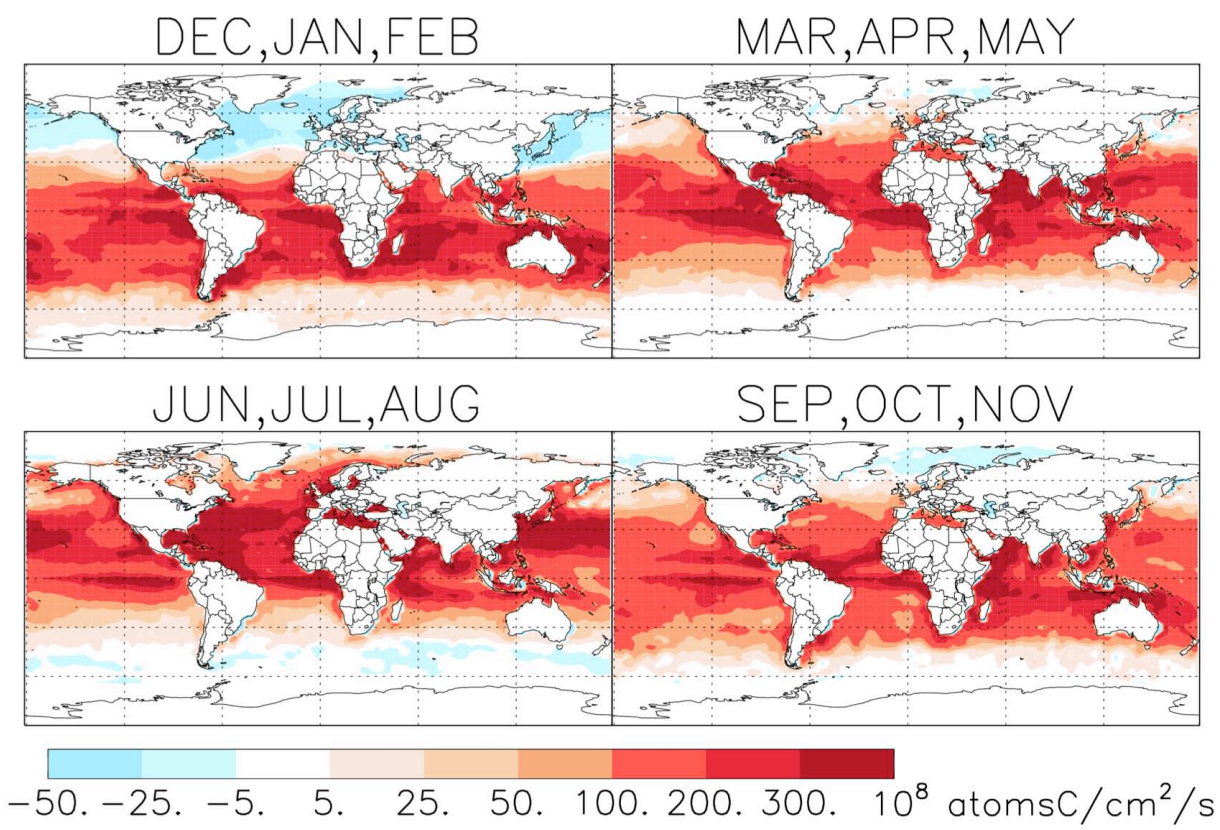

Fig. 6. Net simulated air-sea acetaldehyde flux averaged by season. Red colors indicate a net source of atmospheric acetaldehyde, blue colors a net sink.

We compute the flux of acetaldehyde across the air-sea interface using a standard two-layer model as described in the Supplemental Information. Figure 6 shows the net simulated air-sea acetaldehyde flux averaged by season. Exchange with the atmosphere is bi-directional, but the global net flux in the model is from sea to air and totals $57 \mathrm{Tg} \mathrm{a}^{-1}$. The spatial dis- tribution of the net exchange in Fig. 6 mainly reflects that of the OML photoproduction rate, modulated by the gross airto-sea acetaldehyde flux, with strongest gross ocean uptake downwind of continents (where atmospheric concentrations are elevated) and over cool waters (with higher solubility). 
The net ocean source of acetaldehyde in the model of $57 \mathrm{Tg} \mathrm{a}^{-1}$ globally is larger than the source from terrestrial plants $\left(23 \mathrm{Tg} \mathrm{a}^{-1}\right)$ but less than half of that from atmospheric VOC oxidation $\left(128 \mathrm{Tg} \mathrm{a}^{-1}\right)$. Singh et al. (2004) estimated a much larger oceanic source of acetaldehyde $\left(125 \mathrm{Tg} \mathrm{a}^{-1}\right)$ on the basis of atmospheric measurements over the western Pacific. Our estimate of the net ocean source may be conservative due to the short assumed lifetime for acetaldehyde in the OML and the assumption that acetaldehyde is well-mixed throughout the OML. In Sect. 4 we will evaluate our ocean source estimate in terms of model consistency with aircraft measurements of acetaldehyde and related chemical tracers $\left(\mathrm{PAN}, \mathrm{NO}_{\mathrm{x}}\right)$, and discuss the sensitivity of our results to assumptions in the air-sea flux calculation.

\subsection{Acetaldehyde sinks}

The dominant sink of atmospheric acetaldehyde in the model is oxidation by $\mathrm{OH}$, with a global lifetime of $\tau=0.9 \mathrm{~d}$ due to $\mathrm{OH}$. Figure 1 shows the distribution of the modeled photochemical sink (including a small contribution from photolysis with $\tau=8 \mathrm{~d}$ ), which is highest over the continental source regions. There are also minor losses due to dry $(\tau=60 \mathrm{~d})$ and wet ( $\tau=600 \mathrm{~d}$ ) deposition (Fig. 1).

\section{Simulated acetaldehyde distribution and global source and sink magnitudes}

Table 2 summarizes the global magnitudes for the modeled acetaldehyde sources and sinks. The total source of $213 \mathrm{Tg} \mathrm{a}^{-1}$ from photochemical production $(60 \%)$ and direct emissions from the surface ocean (27\%), the terrestrial biosphere $(11 \%)$, biomass burning $(1.6 \%)$, and anthropogenic sources $(<1 \%)$ is balanced by sinks due to gas-phase oxidation by $\mathrm{OH}(88 \%)$, photolysis $(11 \%)$, and wet + dry deposition $(<2 \%)$. The global atmospheric burden of acetaldehyde in the model is $0.5 \mathrm{Tg}$ and the atmospheric lifetime is $0.8 \mathrm{~d}$.

Figure 7 shows the modeled global distribution of atmospheric acetaldehyde as an annual average, in the boundary layer (considered for this discussion to be $P>800 \mathrm{hPa}$ ) and in the mid-troposphere $(400<P<600 \mathrm{hPa})$. We see annual mean concentrations reaching $1 \mathrm{ppb}$ or more in the continental boundary layer where acetaldehyde and precursor emissions are large. The highest mixing ratios in the model occur over tropical South America and Africa, due to high biogenic emissions of acetaldehyde and precursor alkenes. Regions with enhanced concentrations tend to be localized near sources due to acetaldehyde's short atmospheric lifetime. Over the ocean, boundary layer concentrations are generally $20-200$ ppt with higher levels in continental outflow and in a few locations where the modeled ocean source is strong (e.g., off the Peruvian and Argentinean coasts). In the mid-troposphere, simulated mixing ratios are generally
Table 2. Global Budget of Atmospheric Acetaldehyde.

\begin{tabular}{|c|c|c|}
\hline & Singh et al. $(2004)^{b}$ & This Work \\
\hline \multicolumn{3}{|l|}{ Sources $\left(\mathrm{Tg} \mathrm{a}^{-1}\right)$} \\
\hline Atmospheric production & 35 & 128 \\
\hline Net ocean emission & 125 & 57 \\
\hline Terrestrial plant growth + decay & 35 & 23 \\
\hline Biomass burning & 10 & 3 \\
\hline Anthropogenic emission ${ }^{\mathrm{a}}$ & $<1$ & 2 \\
\hline Total Sources & 205 & 213 \\
\hline \multicolumn{3}{|l|}{ Sinks $\left(\mathrm{Tg} \mathrm{a}^{-1}\right)$} \\
\hline Gas-phase oxidation by $\mathrm{OH}$ & & 188 \\
\hline Photolysis & & 22 \\
\hline Dry + wet deposition & & 3 \\
\hline Total Sinks & & 213 \\
\hline Atmospheric Inventory (Tg) & & 0.5 \\
\hline Atmospheric Lifetime (days) & 1 & 0.8 \\
\hline
\end{tabular}
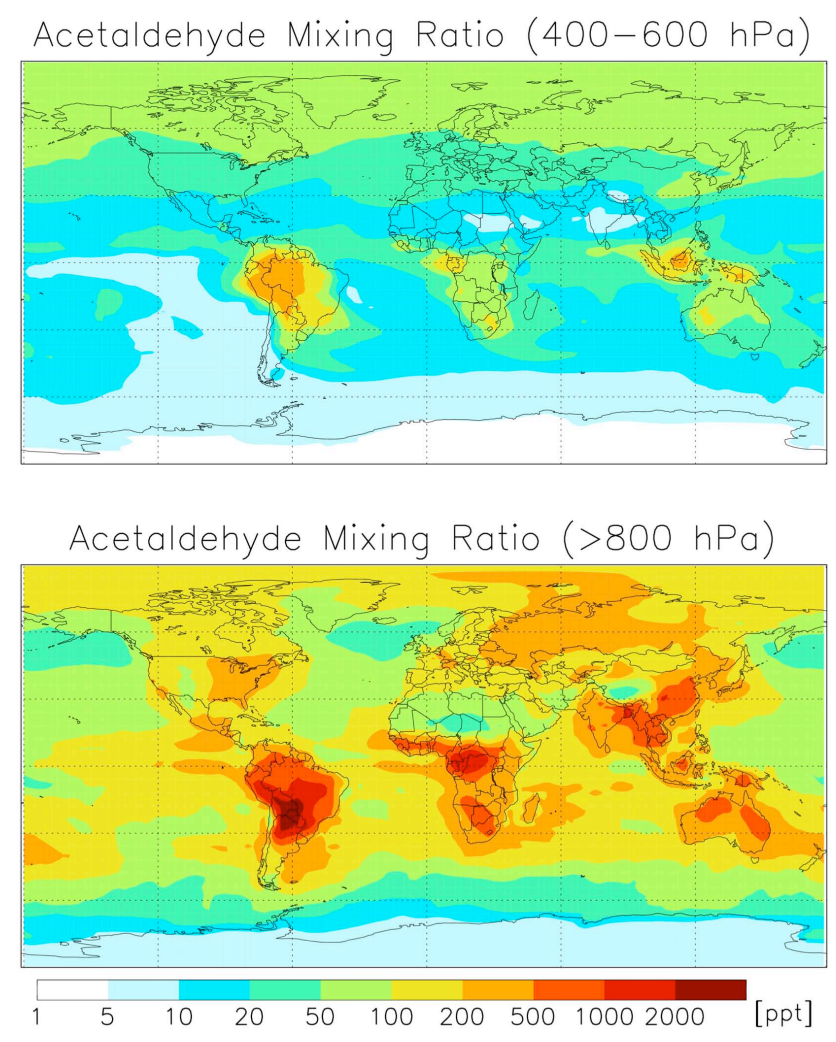

Fig. 7. Simulated global distribution of acetaldehyde mixing ratios (annual average) in the middle and lower troposphere. 
Table 3. Aircraft and Surface Measurements of Acetaldehyde used for Model Evaluation.

\begin{tabular}{|c|c|c|c|c|c|c|}
\hline Exp & iment & Timeframe & Location & Longitude & Latitude & Method and Reference ${ }^{\mathrm{a}}$ \\
\hline \multicolumn{7}{|l|}{ Aircraft Missions } \\
\hline & PEM-Tropics B & Feb-Mar 1999 & Pacific & $148.7^{\circ} \mathrm{E}-84.2^{\circ} \mathrm{W}$ & $36.2^{\circ} \mathrm{S}-35.0^{\circ} \mathrm{N}$ & In-situ GC (Singh et al., 2001) \\
\hline & ITCT-2K2 & Apr-May 2002 & US & $130.2^{\circ} \mathrm{W}-82.3^{\circ} \mathrm{W}$ & $27.7^{\circ} \mathrm{N}-48.1^{\circ} \mathrm{N}$ & PTR-MS (de Gouw and Warneke, 2007) \\
\hline & ITCT-2K4 & Jul-Aug 2004 & US & $85.3^{\circ} \mathrm{W}-59.3^{\circ} \mathrm{W}$ & $27.9^{\circ} \mathrm{N}-53.4^{\circ} \mathrm{N}$ & PTR-MS (de Gouw and Warneke, 2007) \\
\hline & INTEX-A & Jul-Aug 2004 & US, Canada & $139.5^{\circ} \mathrm{W}-36.2^{\circ} \mathrm{W}$ & $27.5^{\circ} \mathrm{N}-53.0^{\circ} \mathrm{N}$ & In-situ GC (Singh et al., 2001) \\
\hline & MILAGRO (C130) & Mar 2006 & Mexico & $105.2^{\circ} \mathrm{W}-88.7^{\circ} \mathrm{W}$ & $16.6^{\circ} \mathrm{N}-39.9^{\circ} \mathrm{N}$ & In-situ GC (Apel et al., 2003) \\
\hline & MILAGRO (DC8) & Mar 2006 & US, Mexico & $122.0^{\circ} \mathrm{W}-86.2^{\circ} \mathrm{W}$ & $14.1^{\circ} \mathrm{N}-39.9^{\circ} \mathrm{N}$ & In-situ GC (Singh et al., 2001) \\
\hline & INTEX-B (C130) & Apr-May 2006 & US & $141.0^{\circ} \mathrm{W}-104.9^{\circ} \mathrm{W}$ & $35.5^{\circ} \mathrm{N}-53.1^{\circ} \mathrm{N}$ & In-situ GC (Apel et al., 2003) \\
\hline & INTEX-B (DC8) & Apr-May 2006 & Pacific & $175.4^{\circ} \mathrm{E}-97.4^{\circ} \mathrm{W}$ & $19.0^{\circ} \mathrm{N}-62.1^{\circ} \mathrm{N}$ & In-situ GC (Singh et al., 2001) \\
\hline & TEXAQS-II & Sep-Oct 2006 & US & $99.6^{\circ} \mathrm{W}-82.5^{\circ} \mathrm{W}$ & $27.5^{\circ} \mathrm{N}-34.2^{\circ} \mathrm{N}$ & PTR-MS (de Gouw and Warneke, 2007) \\
\hline & GABRIEL & Oct 2005 & Surinam & $58.9^{\circ} \mathrm{W}-51.0^{\circ} \mathrm{W}$ & $3.5^{\circ} \mathrm{N}-6.0^{\circ} \mathrm{N}$ & PTR-MS (Eerdekens et al., 2009) \\
\hline & TROFFEE & Sep 2004 & Brazil & $60.3^{\circ} \mathrm{W}-47.7^{\circ} \mathrm{W}$ & $2.6^{\circ} \mathrm{S}-22.8^{\circ} \mathrm{S}$ & PTR-MS (Karl et al., 2007) \\
\hline \multicolumn{7}{|l|}{ Surface Sites } \\
\hline & Brownsberg & Oct 2005 & Surinam & $55.2^{\circ} \mathrm{W}$ & $4.9^{\circ} \mathrm{N}$ & PTR-MS (Eerdekens et al., 2009) \\
\hline & Hohenpeissenberg & Jul 2004 & Germany & $11.0^{\circ} \mathrm{E}$ & $47.8^{\circ} \mathrm{N}$ & PTR-MS (Bartenbach et al., 2007) \\
\hline & Hyytiälä & Jul-Aug 2006-2007 & Finland & $24.3^{\circ} \mathrm{E}$ & $61.9^{\circ} \mathrm{N}$ & PTR-MS (Lappalainen et al., 2009) \\
\hline & Lille Valby & Jul 1995 & Denmark & $12.6^{\circ} \mathrm{E}$ & $55.7^{\circ} \mathrm{N}$ & DNPH (Christensen et al., 2000) \\
\hline & Black Forest & Sep 1992 & Germany & $7.9^{\circ} \mathrm{E}$ & $47.9^{\circ} \mathrm{N}$ & DNPH (Slemr et al., 1996) \\
\hline & EMEP (8 sites) & Jul-Aug 1992-1995 & Europe & $7.1^{\circ} \mathrm{E}-21.2^{\circ} \mathrm{E}$ & $42.1^{\circ} \mathrm{N}-78.9^{\circ} \mathrm{N}$ & DNPH (Solberg et al., 1996) \\
\hline
\end{tabular}

${ }^{\mathrm{a}} \mathrm{GC}=$ gas chromatography; PTR-MS = proton-transfer reaction mass spectrometry; DNPH = 2,4-dinitrophenylhydrazine.

5-50 ppt (annual average), with higher values over tropical South America, Africa and Indonesia.

\section{Model simulation of atmospheric observations}

In this section we use measured acetaldehyde concentrations and tracer-tracer correlations from an ensemble of worldwide airborne and surface datasets to evaluate the GEOS-Chem simulation, and interpret the model-measurement comparisons in terms of acetaldehyde source and sink processes. We compare model output for 2004 to observations from multiple years under the assumption that interannual variability is small compared to other sources of model error (a 3-year sensitivity run showed maximum interannual differences of $<10 \%$ for all acetaldehyde sources in the model). Table 3 gives the details of the airborne and surface acetaldehyde measurements used here.

\subsection{Continental boundary layer}

Figure 8 compares simulated boundary layer $(P>800 \mathrm{hPa})$ concentrations over Europe during July-August and over tropical South America during September-October to surface and airborne measurements collected during those times (Slemr et al., 1996; Solberg et al., 1996; Christensen et al., 2000; Bartenbach et al., 2007; Karl et al., 2007; Eerdekens et al., 2009; Lappalainen et al., 2009). The model captures the large-scale features and gradients seen in the measurements, which include remote, rural, polluted, and forested sites and span $94^{\circ}$ of latitude. There does not appear to be a persistent bias in the model relative to these continental boundary-layer datasets. The model is biased low relative to the two Italian datasets, which are affected by local anthropogenic sources. As we will see, this modelmeasurement discrepancy is also present over polluted areas in North America.

There have been a number of recent aircraft campaigns over North America, allowing a more detailed model evaluation for that region. Figure 9 shows boundary layer acetaldehyde measurements during ITCT-2K2 (Parrish et al., 2004), ITCT-2K4 (Fehsenfeld et al., 2006), INTEX-A (Singh et al., 2006), INTEX-B (Singh et al., 2009), MILAGRO (Molina et al., 2010), and TEXAQS-II (Parrish et al., 2009) mapped onto the model grid, compared to model results sampled along the flight tracks at the time of measurement. Biomass burning plumes (diagnosed by $\mathrm{CH}_{3} \mathrm{CN}>225 \mathrm{ppt}$ or $\mathrm{HCN}>500 \mathrm{ppt}$ ) and fresh pollution plumes $\left(\mathrm{NO}_{2}>4 \mathrm{ppb}\right.$ or $\left.\mathrm{NO}_{\mathrm{x}}: \mathrm{NO}_{\mathrm{y}}>0.4\right)$ have been removed prior to gridding since they are not captured at the $2^{\circ} \times 2.5^{\circ}$ model resolution.

Observed concentrations in Fig. 9 are similar to those simulated by GEOS-Chem, except over and downwind of polluted regions (US Northeast, Mexico City, southern California) where a low model bias is evident. The discrepancy is unlikely to reflect an underestimate of direct urban/industrial emissions: this acetaldehyde source is small in the model ( $<2 \%$ of secondary production), and well-constrained by observed emission ratios relative to $\mathrm{CO}$ as discussed earlier. The problem appears specific to polluted areas, which argues against a sink (i.e., $\mathrm{OH}$ ) overestimate as the main explanation. Also, the fact that the predominant sources as well as sinks of acetaldehyde are photochemical weakens the sensitivity to model $\mathrm{OH}$. The measurement artifacts mentioned in Sect. 1 have been shown to be most significant in 

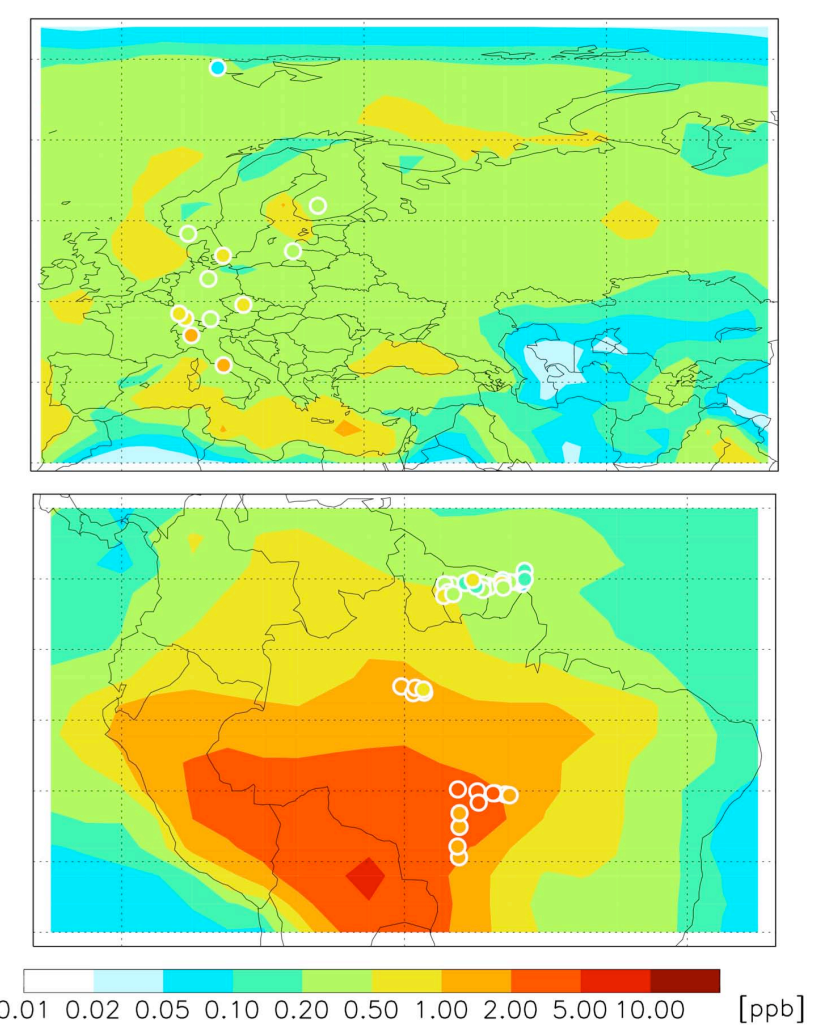

Fig. 8. Acetaldehyde in the boundary layer $(P>800 \mathrm{hPa})$ over Europe and South America. Top: simulated concentrations over Europe in July-August are compared to an ensemble of surface measurements during those months (Slemr et al., 1996; Solberg et al., 1996; Christensen et al., 2000; Bartenbach et al., 2007; Lappalainen et al., 2009). Bottom: simulated concentrations over South America during September-October are compared to aircraft and surface measurements from the GABRIEL (Eerdekens et al., 2009) and TROFFEE (Karl et al., 2007) campaigns.

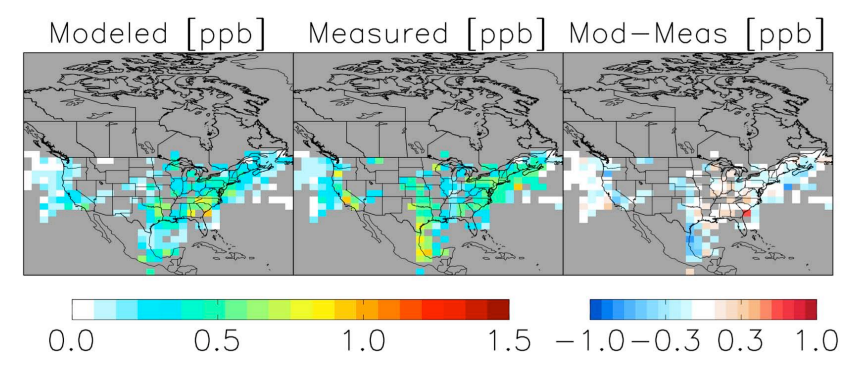

Fig. 9. Acetaldehyde in the boundary layer $(P>800 \mathrm{hPa})$ over North America. Simulated concentrations are compared to measurements from an ensemble of aircraft campaigns, with the observations mapped on the $2^{\circ} \times 2.5^{\circ}$ model grid and the model sampled at the same time and day of year as the measurements. The eastern North America data (INTEX-A, ITCT-2K4) are for July-August, and the western data (ITCT-2K2, INTEX-B) are for April-May. Data over the Gulf Coast and Mexico are for March (MILAGRO) and September-October (TEXAQS-II). clean background air, and so this does not seem a tenable explanation either. The low model bias over polluted regions could be due to an emission underestimate for anthropogenic VOCs that are precursors of acetaldehyde, or to insufficient acetaldehyde production during the photochemical oxidation of those VOCs.

Xiao et al. (2008) and Warneke et al. (2007) have shown that the US NEI-99 inventory tends to underestimate ethane and propane emissions. We have adjusted the modeled emissions accordingly (Sect. 2.3.2), but emissions of other VOCs may also be underestimated. Also, Sommariva et al. (2008) carried out a detailed investigation of oxygenated VOC production in urban plumes using MCMv3.1 and ITCT-2K4 aircraft measurements. With precursor concentrations constrained by measurements, they found that MCMv3.1 underpredicted the photochemical production of acetaldehyde by $50 \%$ or more during the first $1-2$ days of processing. It appears that current models are missing an important fraction of the acetaldehyde source in urban air.

\subsection{Vertical profiles}

Figure 10 shows measured acetaldehyde profiles (black) over the North American continent and over the ocean compared to modeled profiles from GEOS-Chem (red). As above, fresh pollution and biomass burning plumes have been filtered out, and the model sampled along the aircraft flight tracks at the time and day of measurement. For the marine profiles, polluted air $(\mathrm{CO}>150 \mathrm{ppb})$ has been removed to better isolate the effect of air-sea exchange.

Over land (Fig. 10 panels A-D), we see elevated concentrations near the surface and a strong decrease with altitude, due to the surface source for acetaldehyde and its precursors combined with its short atmospheric lifetime. In the continental boundary layer, the model underestimate in polluted air is again apparent (e.g., near Houston during TEXAQSII and over the US Northeast during ITCT-2K4), but simulated concentrations agree well with measurements from the more geographically extensive INTEX-A campaign.

Over the ocean (Fig. 10 panels E-I) we generally see lower acetaldehyde concentrations and little vertical gradient. In the MBL, the model is biased low relative to ITCT-2K4 aircraft data (off the coast of the US Northeast), but is generally in the same range as observations from the other campaigns. The lack of persistent model bias in surface air over the ocean provides some support for our estimate of the oceanic acetaldehyde source. On the other hand, the modeled vertical gradient over the ocean is steeper than observed for several of the campaigns (the two are similar for the DC8 measurements during INTEX-B). The known measurement artifacts for acetaldehyde in clean air (Northway et al., 2004; Apel et al., 2008) make it difficult to directly test the modeled ocean source of acetaldehyde; we return to this point later.

The observed free tropospheric concentrations are much higher than the model for all marine and continental profiles 

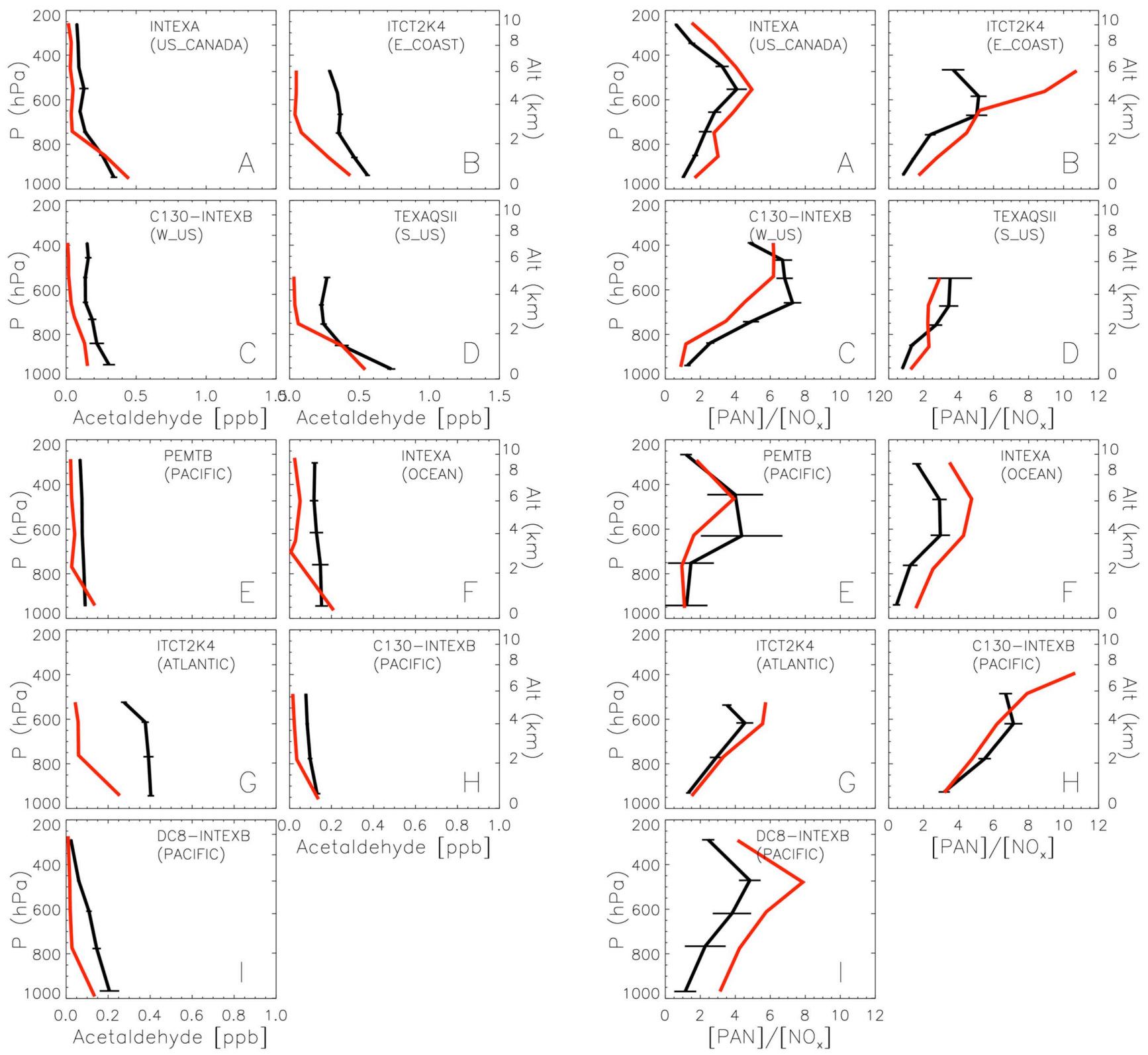

Fig. 10. Vertical profiles of acetaldehyde mixing ratio over the North American continent (A-D) and over the ocean (E-I). Aircraft measurements are shown in black with the error bars indicating twice the standard error around the mean for each altitude bin. Red lines show the GEOS-Chem simulated profiles with the model sampled at the same time and day of year as the observations. Note the differing $\mathrm{x}$-axis scales for the land and ocean profiles. See text for details.

in Fig. 10. This problem was noted previously over the Pacific and North America (Staudt et al., 2003; Singh et al., 2004; Kwan et al., 2006), but those earlier comparisons were based on a less thorough description of acetaldehyde sources and chemistry than presented in this paper. We see here that the issue persists with the improved simulation, and points to

Fig. 11. Vertical profiles of $\mathrm{PAN}: \mathrm{NO}_{\mathrm{x}}$ ratio over the North American continent (A-D) and over the ocean (E-I). Colors as in Fig. 10. See text for details.

a general discrepancy between the high measured acetaldehyde concentrations in the free troposphere and present understanding of its sources and atmospheric lifetime.

In the following section we evaluate the acetaldehyde simulation indirectly in terms of consistency with measured PAN and $\mathrm{NO}_{\mathrm{x}}$. Hudman et al. (2007) found the vertical concentration profiles for $\mathrm{NO}_{\mathrm{x}}$ and PAN to be individually well-simulated by GEOS-Chem compared to INTEX-A and ITCT-2K4 measurements, after accounting for recent North American emission reductions and a more realistic lightning 
source. We focus here on PAN: $\mathrm{NO}_{\mathrm{x}}$ ratio comparisons in the free troposphere and over the ocean, where the low acetaldehyde levels (and possible measurement artifacts) make direct comparison of simulated and observed acetaldehyde concentrations more uncertain.

\subsection{PAN:NO $\mathrm{N}_{\mathrm{X}}$ ratio}

Since acetaldehyde, PAN, and $\mathrm{NO}_{\mathrm{x}}$ are related by welldefined chemistry, measured PAN and $\mathrm{NO}_{\mathrm{x}}$ concentrations provide an additional constraint with which to test the model. Any severe model bias for acetaldehyde should also manifest as a corresponding bias in the simulated PAN:NO $\mathrm{Natio}_{\mathrm{x}}$

Figure 11 compares vertical profiles of measured and simulated PAN: $\mathrm{NO}_{\mathrm{x}}$ ratios for the same aircraft campaigns shown in Fig. 10. The methods used to measure these species have been previously published and are summarized by Raper et al. (2001) for PEM-TB, Singh et al. (2006) for INTEX-A, Fehsenfeld et al. (2006) for ITCT-2K4, Singh et al. (2009) for INTEX-B (DC8 aircraft), Parrish et al. (2009) for TEXAQS-II, and by Slusher et al. (2004) and Weinheimer et al. (1993) for INTEX-B (C130 aircraft). In all cases fresh pollution and biomass burning plumes have been filtered out as above.

In contrast to the persistent and severe model underestimate of acetaldehyde concentrations relative to the free tropospheric measurements, we see that the PAN: $\mathrm{NO}_{\mathrm{x}}$ ratio is relatively well-simulated. There are cases where the measured ratio is higher than the model in the free troposphere (e.g., C130 data from INTEX-B), which would be consistent with a model underestimate of acetaldehyde. However, taken together, the PAN: $\mathrm{NO}_{\mathrm{x}}$ comparisons provide no corroboration for a large-scale missing source of acetaldehyde in the free troposphere. A model sensitivity run in which we imposed a minimum acetaldehyde concentration of $100 \mathrm{ppt}$ throughout the troposphere (an approximate lower bound based on the average profiles in Fig. 10) resulted in unrealistically high simulated PAN: $\mathrm{NO}_{\mathrm{x}}$ ratios: up to $5 \times$ higher than observed.

In surface air over the ocean, the modeled PAN: $\mathrm{NO}_{\mathrm{x}}$ ratios agree well with the measurements (Fig. 11). We estimated the ocean acetaldehyde source using a conservative assumption for its OML lifetime based on available data (Mopper and Kieber, 1991; Zhou and Mopper, 1997), leading to a computed net ocean source of $57 \mathrm{Tg} \mathrm{a}^{-1}$. A longer assumed OML lifetime would result in a larger ocean source in the model, which would agree better with the previous estimate of $125 \mathrm{Tg} \mathrm{a}^{-1}$ (Singh et al., 2004). However, a sensitivity run with $125 \mathrm{Tg} \mathrm{a}^{-1}$ net oceanic emission produced PAN: $\mathrm{NO}_{\mathrm{x}}$ vertical gradients over the ocean less steep than observed, an overestimate of atmospheric acetaldehyde in the marine boundary layer compared to most of the airborne datasets, and higher acetaldehyde concentrations in the surface ocean than seems tenable based on the range of observations (Mopper and Kieber, 1991; Zhou and Mopper, 1997). We con- clude that the balance of evidence argues against a significantly larger ocean source than used here.

\section{Role of ethanol as acetaldehyde source}

Ethanol is receiving attention as a renewable fuel with the potential to reduce our reliance on fossil fuels and mitigate global warming. Analyses to date indicate that a transition to ethanol fuels could cause significant air quality penalties or benefits, depending on how the ethanol is produced (Hill et al., 2006; Jacobson, 2007; Hill et al., 2009): in monetary terms, health impacts may outweigh greenhouse gas impacts. A study by Jacobson (2007) predicts that a switch to E85 ethanol fuel ( $85 \%$ ethanol fuel, $15 \%$ gasoline) in the US would increase air pollution-related mortality, hospitalization, and asthma relative to $100 \%$ gasoline. Projected air quality impacts of ethanol fuel use are closely tied to the associated increase in acetaldehyde levels, from direct emissions and from photochemical oxidation of unburned ethanol (65-75\% of organic gas emissions from E85 automobiles consist of unburned ethanol itself; Black, 1991; Jacobson, 2007).

Actual air pollution impacts of ethanol use will depend on the ethanol and acetaldehyde increases relative to their existing sources. We have provided here the first detailed assessment of existing sources for these compounds, totaling 25 and $213 \mathrm{Tg} \mathrm{a}^{-1}$ globally. Jacobson (2007) estimates that converting the entire US vehicle fleet to E85 would increase acetaldehyde emissions by $0.14 \mathrm{Tg} \mathrm{a}^{-1}$ and ethanol emissions by $2.1 \mathrm{Tg} \mathrm{a}^{-1}$ (considering tailpipe emissions only). These two compounds made up $76 \%$ by mass of the total projected non-methane VOC emission increase, and $80 \%$ of the increase for potential acetaldehyde precursors (excluding $\mathrm{C} 1$ compounds, unreactive compounds, and ethene). Accounting for a $95 \%$ acetaldehyde yield from ethanol oxidation and a $23 \%$ depositional sink for ethanol (see above) this translates to an approximate total acetaldehyde source increase of $1.6 \mathrm{Tg} \mathrm{a}^{-1}$ for the US.

By comparison, we estimate the current US ethanol source at $1.3 \mathrm{Tg} \mathrm{a}^{-1}$, including $74 \%$ from biogenic emissions. We estimate the current US acetaldehyde source at $7.8 \mathrm{Tg} \mathrm{a}^{-1}$, including direct emissions and secondary production but excluding the ocean source. Here we consider only photochemical production occurring over the US; a conservative assumption since VOC oxidation continues as air moves offshore. We conclude that the projected increase in ethanol emissions for a US transition to E85 is comparable to the existing US ethanol source ( 2.1 versus $1.3 \mathrm{Tg} \mathrm{a}^{-1}$ ), and that the associated acetaldehyde source increase is equivalent to only $21 \%$ of the current US acetaldehyde source. Studies investigating how ethanol fuel use will affect air quality need to adequately account for these existing sources. 


\section{Key uncertainties and outstanding issues}

In this section we examine the main sources of uncertainty in the model evaluation and identify observational needs for refining the acetaldehyde source and sink estimates presented here. The acetaldehyde lifetime in the OML is a key parameter for estimating the ocean source. Published estimates imply values between $0.3-12 \mathrm{~h}$, but with no information on how it might vary in space and time (Mopper and Kieber, 1991; Zhou and Mopper, 1997). As a result, our computed ocean source carries significant uncertainty. Atmospheric measurements of acetaldehyde and PAN: $\mathrm{NO}_{\mathrm{x}}$ provide some support for our estimate of the sea-to-air flux and bounds on its magnitude, but additional measurements of acetaldehyde and its turnover rates in the OML as well as air-sea flux would be valuable constraints.

Another area of uncertainty is the source rate of precursor VOCs. Bottom-up uncertainties in VOC emissions can be large (Xiao et al., 2008). Also, for simple precursors such as ethane and propene the time-dependent acetaldehyde yield is well known, but uncertainties are higher for more complex compounds including isoprene. Measurements of acetaldehyde itself provide an integrating constraint on the product of precursor emissions and acetaldehyde yield. We have shown here that our acetaldehyde simulation captures the large-scale patterns and gradients in surface air observations, but is biased low in polluted air. In contrast, there was no model bias evident for formaldehyde concentrations relative to aircraft measurements over the eastern US (Millet et al., 2006).

Biogenic emissions from terrestrial plants do not represent a dominant term in the overall acetaldehyde budget, but the bottom-up uncertainty in this source is probably at least $50 \%$ based on the range of observed canopy-scale emission rates (see Supplemental Information). Simulated acetaldehyde concentrations over the US Southeast and over the Amazon are generally similar to available aircraft and surface measurements, which lends support to the MEGANv2.1 emissions. Ethanol measurements are much sparser and more are needed to better constrain its present-day budget and importance as an acetaldehyde source. More information is also needed to better parameterize the effect of soil moisture on emissions for both compounds.

Other potential sources of error in the acetaldehyde simulation include boundary layer venting and model $\mathrm{OH}$. Previous work with GEOS-Chem argues against a persistent model bias in the former (Millet et al., 2006; Xiao et al., 2007; Hudman et al., 2008). The error in mean OH is estimated at $\pm 10 \%$ for GEOS-Chem (Xiao et al., 2008), and in any case acetaldehyde is buffered to a degree since it is both produced and destroyed photochemically.

\section{Conclusions}

We used a global 3-D chemical transport model (GEOSChem) together with an ensemble of surface, airborne, and satellite observations to carry out the first detailed analysis of the global acetaldehyde budget. We carried out extensive updates to the GEOS-Chem chemical mechanism to more accurately represent the production of acetaldehyde from VOC oxidation, and the resulting chemical yields of acetaldehyde are in general agreement with those from the Master Chemical Mechanism (MCMv3.1). The dominant global acetaldehyde source in the model is photochemical $\left(128 \mathrm{Tg} \mathrm{a}^{-1}\right)$, most importantly from oxidation of alkanes, alkenes, ethanol, and isoprene. This is a factor of 4 larger than the previous estimate (30 $\mathrm{Tg} \mathrm{a}^{-1}$; Singh et al., 2004); the present work uses a more comprehensive and up-to-date treatment of precursor emissions and their oxidation pathways.

Monthly distributions of colored dissolved organic matter $(\mathrm{CDOM})$ in the world's oceans derived from satellite ocean color observations allow us to estimate the oceanic source of acetaldehyde, based on published yields of acetaldehyde from CDOM photodegradation (Kieber et al., 1990). This is an important step forward as the first calculation of the acetaldehyde sea-to-air flux that is tied to actual production rates in the ocean mixed layer (OML) as constrained by observations. The resulting net global sea-to-air flux is $57 \mathrm{Tg} \mathrm{a}^{-1}$, the second largest source term in the model but a factor of two smaller than the atmospheric source from VOC oxidation. It is also a factor of two smaller than the previous estimate of Singh et al. (2004), which was based on atmospheric measurements over the Pacific Ocean. Our representation of the ocean source yields predicted acetaldehyde concentrations over the ocean surface that are similar to aircraft measurements; however, the modeled vertical gradient over the ocean is too steep relative to the observations in several cases. Quantitative evaluation of the modeled ocean source against atmospheric acetaldehyde observations is complicated by known measurement artifacts in clean air. Simulated PAN: $\mathrm{NO}_{\mathrm{x}}$ ratios agree well with observations over the ocean which provides some support for the modeled ocean source; however, more measurements are needed to reduce its uncertainty.

Terrestrial sources of acetaldehyde in the model include $23 \mathrm{Tg} \mathrm{a}^{-1}$ from vegetation and $3 \mathrm{Tg} \mathrm{a}^{-1}$ from biomass burning. Direct anthropogenic emissions (including biofuel) are well-constrained by measured emission ratios relative to $\mathrm{CO}$ and amount to $2 \mathrm{Tg} \mathrm{a}^{-1}$ globally, $1 \%$ of the total source. Reaction with $\mathrm{OH}$ is the main acetaldehyde sink, accounting for $88 \%$ of the total loss in the model. With photolysis $(11 \%)$ and wet + dry deposition $(<2 \%)$, the overall atmospheric lifetime for acetaldehyde in the model is 0.8 days.

Simulated acetaldehyde mixing ratios generally agree well with aircraft and surface measurements in the continental boundary layer, capturing broad patterns of concentration 
and variability over North America, Europe, and the Amazon. There is no evidence of a persistent bias that would suggest a significant error in the primary and secondary terrestrial sources in the model. An exception is the low bias compared to aircraft measurements in polluted air, which must be due to an underestimate of anthropogenic hydrocarbon emissions or of the associated acetaldehyde yield. Current models appear to be missing an important fraction of the acetaldehyde source in polluted air.

We see a severe model-measurement discrepancy in the free troposphere. For all of the aircraft campaigns examined here, the observed acetaldehyde levels are substantially higher than predicted by GEOS-Chem. The average free tropospheric bias ranges from a factor of 2-30, depending on location and altitude. On the other hand, we find that the corresponding PAN: $\mathrm{NO}_{\mathrm{x}}$ ratios are well-simulated by the model. This is an apparent contradiction based on present understanding of acetaldehyde and PAN chemistry, since such elevated acetaldehyde concentrations should also manifest as high PAN: $\mathrm{NO}_{\mathrm{x}}$ ratios compared to the model. We conclude that there is no strong evidence for a large missing acetaldehyde source in the free troposphere.

Our work lays the groundwork for an improved assessment of the potential effects of ethanol fuel on air quality, since in the atmosphere ethanol is oxidized to acetaldehyde nearly quantitatively. We find that current US acetaldehyde sources $\left(7.8 \mathrm{Tg} \mathrm{a}^{-1}\right)$ are nearly $5 \times$ greater than the increase predicted for a full vehicle fleet transition to ethanol fuel (1.6 $\mathrm{Tg} \mathrm{a}^{-1}$; Jacobson, 2007). Current ethanol sources are less well constrained but appear to be predominantly biogenic. We estimate current US emission at $1.3 \mathrm{Tg} \mathrm{a}^{-1}$, compared to an expected increase of $2.1 \mathrm{Tg} \mathrm{a}^{-1}$ for a transition to ethanol fuel.

Acknowledgements. We gratefully acknowledge the science teams for the GABRIEL, INTEX-A, INTEX-B, ITCT-2K2, ITCT-2K4, MILAGRO, PEM-TB, TEXAQS-II, and TROFFEE aircraft experiments. Particular thanks go to B. Brune, X. Ren, J. Mao, T. Ryerson, G. Huey, A. Weinheimer, and R. Cohen for the use of their airborne $\mathrm{NO}$ and $\mathrm{NO}_{2}$ measurements. $\mathrm{MPB}$ and PIP acknowledge funding from NERC (grant NE/D001471).

Edited by: P. Monks

\section{References}

Altshuller, A. P.: Chemical reactions and transport of alkanes and their products in the troposphere, J. Atmos. Chem., 12, 19-61, 1991a.

Altshuller, A. P.: Estimating product yields of carbon-containing products from the atmospheric photooxidation of ambient air alkenes, J. Atmos. Chem., 13, 131-154, 1991b.

Andreae, M. O. and Merlet, P.: Emission of trace gases and aerosols from biomass burning, Global Biogeochem. Cy., 15, 955-966, 2001.
Apel, E. C., Hills, A. J., Lueb, R., Zindel, S., Eisele, S., and Riemer, D. D.: A fast-GC/MS system to measure C-2 to C-4 carbonyls and methanol aboard aircraft, J. Geophys. Res., 108, 8794, doi:10.1029/2002JD003199, 2003.

Apel, E. C., Brauers, T., Koppmann, R., Bandowe, B., Bossmeyer, J., Holzke, C., Tillmann, R., Wahner, A., Wegener, R., Brunner, A., Jocher, M., Ruuskanen, T., Spirig, C., Steigner, D., Steinbrecher, R., Alvarez, E. G., Muller, K., Burrows, J. P., Schade, G., Solomon, S. J., Ladstatter-Weissenmayer, A., Simmonds, P., Young, D., Hopkins, J. R., Lewis, A. C., Legreid, G., Reimann, S., Hansel, A., Wisthaler, A., Blake, R. S., Ellis, A. M., Monks, P. S., and Wyche, K. P.: Intercomparison of oxygenated volatile organic compound measurements at the SAPHIR atmosphere simulation chamber, J. Geophys. Res., 113, D20307, doi:10.1029/2008JD009865, 2008.

Atkinson, R., Baulch, D. L., Cox, R. A., Crowley, J. N., Hampson, R. F., Hynes, R. G., Jenkin, M. E., Rossi, M. J., and Troe, J.: Evaluated kinetic and photochemical data for atmospheric chemistry: Volume II - gas phase reactions of organic species, Atmos. Chem. Phys., 6, 3625-4055, 2006,

http://www.atmos-chem-phys.net/6/3625/2006/.

Ban-Weiss, G. A., McLaughlin, J. P., Harley, R. A., Kean, A. J., Grosjean, E., and Grosjean, D.: Carbonyl and nitrogen dioxide emissions from gasoline- and diesel-powered motor vehicles, Environ. Sci. Technol., 42, 3944-3950, 2008.

Bartenbach, S., Williams, J., Plass-Dulmer, C., Berresheim, H., and Lelieveld, J.: In-situ measurement of reactive hydrocarbons at Hohenpeissenberg with comprehensive two-dimensional gas chromatography (GC $\times$ GC-FID): use in estimating $\mathrm{HO}$ and $\mathrm{NO}_{3}$, Atmos. Chem. Phys., 7, 1-14, 2007, http://www.atmos-chem-phys.net/7/1/2007/.

Bey, I., Jacob, D. J., Yantosca, R. M., Logan, J. A., Field, B. D., Fiore, A. M., Li, Q. B., Liu, H. G. Y., Mickley, L. J., and Schultz, M. G.: Global modeling of tropospheric chemistry with assimilated meteorology: Model description and evaluation, J. Geophys. Res., 106, 23073-23095, 2001.

Black, F.: An overview of the technical implications of methanol and ethanol as highway motor vehicle fuels, EPA/600/D-91/239, US EPA, Washington DC, USA, 1991.

Bloss, C., Wagner, V., Jenkin, M. E., Volkamer, R., Bloss, W. J., Lee, J. D., Heard, D. E., Wirtz, K., Martin-Reviejo, M., Rea, G., Wenger, J. C., and Pilling, M. J.: Development of a detailed chemical mechanism (MCMv3.1) for the atmospheric oxidation of aromatic hydrocarbons, Atmos. Chem. Phys., 5, 641-664, 2005, http://www.atmos-chem-phys.net/5/641/2005/.

Christensen, C. S., Skov, H., Nielsen, T., and Lohse, C.: Temporal variation of carbonyl compound concentrations at a semi-rural site in Denmark, Atmos. Environ., 34, 287-296, 2000.

Christian, T. J., Kleiss, B., Yokelson, R. J., Holzinger, R., Crutzen, P. J., Hao, W. M., Saharjo, B. H., and Ward, D. E.: Comprehensive laboratory measurements of biomass-burning emissions: 1 . Emissions from Indonesian, African, and other fuels, J. Geophys. Res., 108, 4719, doi:10.1029/2003JD003704, 2003.

Cojocariu, C., Kreuzwieser, J., and Rennenberg, H.: Correlation of short-chained carbonyls emitted from Picea abies with physiological and environmental parameters, New Phytologist, 162, 717-727, 2004.

Cojocariu, C., Escher, P., Haberle, K. H., Matyssek, R., Rennenberg, H., and Kreuzwieser, J.: The effect of ozone on the emis- 
sion of carbonyls from leaves of adult Fagus sylvatica, Plant Cell Environ., 28, 603-611, 2005.

Colomb, A., Gros, V., Alvain, S., Sarda-Esteve, R., Bonsang, B., Moulin, C., Klupfel, T., and Williams, J.: Variation of atmospheric volatile organic compounds over the Southern Indian Ocean (30-49 degrees S), Environ. Chem., 6, 70-82, 2009.

Custer, T. and Schade, G.: Methanol and acetaldehyde fluxes over ryegrass, Tellus B - Chem. Phys. Meteorol., 59, 673-684, 2007.

de Gouw, J. and Warneke, C.: Measurements of volatile organic compounds in the earths atmosphere using proton-transferreaction mass spectrometry, Mass Spectrom. Rev., 26, 223-257, 2007.

de Gouw, J. A., Howard, C. J., Custer, T. G., and Fall, R.: Emissions of volatile organic compounds from cut grass and clover are enhanced during the drying process, Geophys. Res. Lett., 26, 811-814, 1999.

de Gouw, J. A., Howard, C. J., Custer, T. G., Baker, B. M., and Fall, R.: Proton-transfer chemical-ionization mass spectrometry allows real-time analysis of volatile organic compounds released from cutting and drying of crops, Environ. Sci. Technol., 34, 2640-2648, 2000.

de Gouw, J. A., Middlebrook, A. M., Warneke, C., Goldan, P. D., Kuster, W. C., Roberts, J. M., Fehsenfeld, F. C., Worsnop, D. R., Canagaratna, M. R., Pszenny, A. A. P., Keene, W. C., Marchewka, M., Bertman, S. B., and Bates, T. S.: Budget of organic carbon in a polluted atmosphere: Results from the New England Air Quality Study in 2002, J. Geophys. Res., 110, D16305, doi:10.1029/2004JD005623, 2005.

de Gouw, J. A., Welsh-Bon, D., Warneke, C., Kuster, W. C., Alexander, L., Baker, A. K., Beyersdorf, A. J., Blake, D. R., Canagaratna, M., Celada, A. T., Huey, L. G., Junkermann, W., Onasch, T. B., Salcido, A., Sjostedt, S. J., Sullivan, A. P., Tanner, D. J., Vargas, O., Weber, R. J., Worsnop, D. R., Yu, X. Y., and Zaveri, R.: Emission and chemistry of organic carbon in the gas and aerosol phase at a sub-urban site near Mexico City in March 2006 during the MILAGRO study, Atmos. Chem. Phys., 9, 3425-3442, 2009,

http://www.atmos-chem-phys.net/9/3425/2009/.

Duncan, B. N., Logan, J. A., Bey, I., Megretskaia, I. A., Yantosca, R. M., Novelli, P. C., Jones, N. B., and Rinsland, C. P.: Global budget of CO, 1988-1997: Source estimates and validation with a global model, J. Geophys. Res., 112, D22301, doi:10.1029/2007JD008459, 2007.

Eerdekens, G., Ganzeveld, L., de Arellano, J. V. G., Klupfel, T., Sinha, V., Yassaa, N., Williams, J., Harder, H., Kubistin, D., Martinez, M., and Lelieveld, J.: Flux estimates of isoprene, methanol and acetone from airborne PTR-MS measurements over the tropical rainforest during the GABRIEL 2005 campaign, Atmos. Chem. Phys., 9, 4207-4227, 2009,

http://www.atmos-chem-phys.net/9/4207/2009/.

Emmerson, K. M. and Evans, M. J.: Comparison of tropospheric gas-phase chemistry schemes for use within global models, Atmos. Chem. Phys., 9, 1831-1845, 2009,

http://www.atmos-chem-phys.net/9/1831/2009/.

EPA: Chemical summary for acetaldehyde, EPA 749-F-94-003a, Office of Pollution Prevention and Toxics, 1994.

EPA NEI 2002 inventory: http://www.epa.gov/oar/data/, last access: 2007.

Fall, R.: Abundant oxygenates in the atmosphere: A biochemical perspective, Chem. Rev., 103, 4941-4951, 2003.

Fehsenfeld, F. C., Ancellet, G., Bates, T. S., Goldstein, A. H., Hardesty, R. M., Honrath, R., Law, K. S., Lewis, A. C., Leaitch, R., McKeen, S., Meagher, J., Parrish, D. D., Pszenny, A. A. P., Russell, P. B., Schlager, H., Seinfeld, J., Talbot, R., and Zbinden, R.: International Consortium for Atmospheric Research on Transport and Transformation (ICARTT): North America to Europe Overview of the 2004 summer field study, J. Geophys. Res., 111, D23S01, doi:10.1029/2006JD007829, 2006.

Filella, I., Penuelas, J., and Seco, R.: Short-chained oxygenated VOC emissions in Pinus halepensis in response to changes in water availability, Acta Physiol. Plant., 31, 311-318, 2009.

GMAO: File Specification for GEOS-5 DAS Gridded Output, version 6.4, http://gmao.gsfc.nasa.gov/operations/, NASA Global Modeling and Assimilation Office (GMAO), 2008.

Grabmer, W., Kreuzwieser, J., Wisthaler, A., Cojocariu, C., Graus, M., Rennenberg, H., Steigner, D., Steinbrecher, R., and Hansel, A.: VOC emissions from Norway spruce (Picea abies L. [Karst]) twigs in the field - Results of a dynamic enclosure study, Atmos. Environ., 40, S128-S137, 2006.

Granier, C., Lamarque, J. F., Mieville, A., Muller, J. F., Olivier, J., Orlando, J., Peters, J., Petron, G., Tyndall, G., and Wallens, S.: POET, a database of surface emissions of ozone precursors, http://www.aero.jussieu.fr/projet/ACCENT/POET.php, 2005.

Greenberg, J. P., Friedli, H., Guenther, A. B., Hanson, D., Harley, P., and Karl, T.: Volatile organic emissions from the distillation and pyrolysis of vegetation, Atmos. Chem. Phys., 6, 81-91, 2006, http://www.atmos-chem-phys.net/6/81/2006/.

Grosjean, D., Williams, E. L., and Grosjean, E.: Atmospheric chemistry of isoprene and of its carbonyl products, Environ. Sci. Technol., 27, 830-840, 1993.

Guenther, A., Baugh, B., Brasseur, G., Greenberg, J., Harley, P., Klinger, L., Serca, D., and Vierling, L.: Isoprene emission estimates and uncertainties for the Central African EXPRESSO study domain, J. Geophys. Res., 104, 30625-30639, 1999.

Guenther, A., Karl, T., Harley, P., Wiedinmyer, C., Palmer, P. I., and Geron, C.: Estimates of global terrestrial isoprene emissions using MEGAN (Model of Emissions of Gases and Aerosols from Nature), Atmos. Chem. Phys., 6, 3181-3210, 2006, http://www.atmos-chem-phys.net/6/3181/2006/.

Hill, J., Nelson, E., Tilman, D., Polasky, S., and Tiffany, D.: Environmental, economic, and energetic costs and benefits of biodiesel and ethanol biofuels, P. Natl. Acad. Sci. USA, 103, 11206-11210, 2006.

Hill, J., Polasky, S., Nelson, E., Tilman, D., Huo, H., Ludwig, L., Neumann, J., Zheng, H. C., and Bonta, D.: Climate change and health costs of air emissions from biofuels and gasoline, P. Natl. Acad. Sci. USA, 106, 2077-2082, 2009.

Holzinger, R., Warneke, C., Hansel, A., Jordan, A., Lindinger, W., Scharffe, D.H., Schade, G., and Crutzen, P.J.: Biomass burning as a source of formaldehyde, acetaldehyde, methanol, acetone, acetonitrile, and hydrogen cyanide, Geophys. Res. Lett., 26, 1161-1164, 1999.

Holzinger, R., Sandoval-Soto, L., Rottenberger, S., Crutzen, P. J., and Kesselmeier, J.: Emissions of volatile organic compounds from Quercus ilex L. measured by Proton Transfer Reaction Mass Spectrometry under different environmental conditions, J. Geophys. Res., 105, 20573-20579, 2000.

Hudman, R. C., Jacob, D. J., Turquety, S., Leibensperger, E. M., 
Murray, L. T., Wu, S., Gilliland, A. B., Avery, M., Bertram, T. H., Brune, W., Cohen, R. C., Dibb, J. E., Flocke, F. M., Fried, A., Holloway, J., Neuman, J. A., Orville, R., Perring, A., Ren, X., Sachse, G. W., Singh, H. B., Swanson, A., and Wooldridge, P. J.: Surface and lightning sources of nitrogen oxides over the United States: Magnitudes, chemical evolution, and outflow, J. Geophys. Res., 112, D12S05, doi:10.1029/2006JD007912, 2007.

Hudman, R. C., Murray, L. T., Jacob, D. J., Millet, D. B., Turquety, S., Wu, S., Blake, D. R., Goldstein, A. H., Holloway, J., and Sachse, G. W.: Biogenic vs. anthropogenic sources of CO over the United States, Geophys. Res. Lett., 35, L04801, doi:10.1029/2007GL032393, 2008.

Jacob, D. J., Field, B. D., Li, Q. B., Blake, D. R., de Gouw, J., Warneke, C., Hansel, A., Wisthaler, A., Singh, H. B., and Guenther, A.: Global budget of methanol: Constraints from atmospheric observations, J. Geophys. Res., 110, D08303, doi:10.1029/2004JD005172, 2005.

Jacobson, M. Z.: Effects of ethanol (E85) versus gasoline vehicles on cancer and mortality in the United States, Environ. Sci. Technol., 41, 4150-4157, 2007.

Jardine, K., Harley, P., Karl, T., Guenther, A., Lerdau, M., and Mak, J. E.: Plant physiological and environmental controls over the exchange of acetaldehyde between forest canopies and the atmosphere, Biogeosciences, 5, 1559-1572, 2008,

http://www.biogeosciences.net/5/1559/2008/.

Karl, T., Guenther, A., Jordan, A., Fall, R., and Lindinger, W.: Eddy covariance measurement of biogenic oxygenated VOC emissions from hay harvesting, Atmos. Environ., 35, 491-495, 2001a.

Karl, T., Guenther, A., Lindinger, C., Jordan, A., Fall, R., and Lindinger, W.: Eddy covariance measurements of oxygenated volatile organic compound fluxes from crop harvesting using a redesigned proton-transfer-reaction mass spectrometer, J. Geophys. Res., 106, 24157-24167, 2001b.

Karl, T., Curtis, A. J., Rosenstiel, T. N., Monson, R. K., and Fall, R.: Transient releases of acetaldehyde from tree leaves - products of a pyruvate overflow mechanism?, Plant Cell Environ., 25, 11211131, 2002.

Karl, T., Guenther, A., Spirig, C., Hansel, A., and Fall, R.: Seasonal variation of biogenic VOC emissions above a mixed hardwood forest in northern Michigan, Geophys. Res. Lett., 30, 2186, doi:10.1029/2003GL018432, 2003.

Karl, T., Potosnak, M., Guenther, A., Clark, D., Walker, J., Herrick, J. D., and Geron, C.: Exchange processes of volatile organic compounds above a tropical rain forest: Implications for modeling tropospheric chemistry above dense vegetation, J. Geophys. Res., 109, D18306, doi:10.1029/2004JD004738, 2004.

Karl, T., Harley, P., Guenther, A., Rasmussen, R., Baker, B., Jardine, K., and Nemitz, E.: The bi-directional exchange of oxygenated VOCs between a loblolly pine (Pinus taeda) plantation and the atmosphere, Atmos. Chem. Phys., 5, 3015-3031, 2005a, http://www.atmos-chem-phys.net/5/3015/2005/.

Karl, T., Harren, F., Warneke, C., de Gouw, J., Grayless, C., and Fall, R.: Senescing grass crops as regional sources of reactive volatile organic compounds, J. Geophys. Res., 110, D15302, doi:10.1029/2005JD005777, 2005b.

Karl, T. G., Christian, T. J., Yokelson, R. J., Artaxo, P., Hao, W. M., and Guenther, A.: The Tropical Forest and Fire Emissions Experiment: method evaluation of volatile organic compound emissions measured by PTR-MS, FTIR, and GC from tropical biomass burning, Atmos. Chem. Phys., 7, 5883-5897, 2007, http://www.atmos-chem-phys.net/7/5883/2007/.

Kesselmeier, J.: Exchange of short-chain oxygenated volatile organic compounds (VOCs) between plants and the atmosphere: A compilation of field and laboratory studies, J. Atmos. Chem., 39, 219-233, 2001.

Kieber, R. J., Zhou, X. L., and Mopper, K.: Formation of carbonyl compounds from UV-induced photodegradation of humic substances in natural waters: Fate of riverine carbon in the sea, Limnol. Oceanogr., 35, 1503-1515, 1990.

Kimmerer, T. W. and Kozlowski, T. T.: Ethylene, ethane, acetaldehyde, and ethanol production by plants under stress, Plant Physiol., 69, 840-847, 1982.

Kimmerer, T. W. and Macdonald, R. C.: Acetaldehyde and ethanol biosynthesis in leaves of plants, Plant Physiol., 84, 1204-1209, 1987.

Kirstine, W., Galbally, I., Ye, Y. R., and Hooper, M.: Emissions of volatile organic compounds (primarily oxygenated species) from pasture, J. Geophys. Res., 103, 10605-10619, 1998.

Kreuzwieser, J., Schnitzler, J. P., and Steinbrecher, R.: Biosynthesis of organic compounds emitted by plants, Plant Biol., 1, 149-159, 1999.

Kreuzwieser, J., Kuhnemann, F., Martis, A., Rennenberg, H., and Urban, W.: Diurnal pattern of acetaldehyde emission by flooded poplar trees, Physiologia Plantarum, 108, 79-86, 2000.

Kreuzwieser, J., Papadopoulou, E., and Rennenberg, H.: Interaction of flooding with carbon metabolism of forest trees, Plant Biol., 6, 299-306, 2004.

Kuhns, H., Knipping, E. M., and Vukovich, J. M.: Development of a United States-Mexico emissions inventory for the Big Bend Regional Aerosol and Visibility Observational (BRAVO) Study, J. Air \& Waste Manage. Assoc., 55, 677-692, 2005.

Kwan, A. J., Crounse, J. D., Clarke, A. D., Shinozuka, Y., Anderson, B. E., Crawford, J. H., Avery, M. A., McNaughton, C. S., Brune, W. H., Singh, H. B., and Wennberg, P. O.: On the flux of oxygenated volatile organic compounds from organic aerosol oxidation, Geophys. Res. Lett., 33, L15815, doi:10.1029/2006GL026144, 2006.

Lappalainen, H. K., Sevanto, S., Back, J., Ruuskanen, T. M., Kolari, P., Taipale, R., Rinne, J., Kulmala, M., and Hari, P.: Daytime concentrations of biogenic volatile organic compounds in a boreal forest canopy and their relation to environmental and biological factors, Atmos. Chem. Phys., 9, 5447-5459, 2009, http://www.atmos-chem-phys.net/9/5447/2009/.

Lee, A., Goldstein, A. H., Kroll, J. H., Ng, N. L., Varutbangkul, V., Flagan, R. C., and Seinfeld, J. H.: Gas-phase products and secondary aerosol yields from the photooxidation of 16 different terpenes, J. Geophys. Res., 111, D17305, doi:10.1029/2006JD007050, 2006.

Madronich, S., and Calvert, J.G.: Permutation reactions of organic peroxy radicals in the troposphere, J. Geophys. Res., 95, 56975715, 1990.

Maritorena, S., Siegel, D. A., and Peterson, A. R.: Optimization of a semianalytical ocean color model for global-scale applications, Appl. Opt., 41, 2705-2714, 2002.

Millet, D. B., Jacob, D. J., Turquety, S., Hudman, R. C., Wu, S., Fried, A., Walega, J., Heikes, B. G., Blake, D. R., Singh, H. B., Anderson, B. E., and Clarke, A. D.: Formaldehyde distribution over North America: Implications for satellite retrievals of 
formaldehyde columns and isoprene emission, J. Geophys. Res., 111, D24S02, doi:10.1029/2005JD006853, 2006.

Millet, D. B., Jacob, D. J., Boersma, K. F., Fu, T. M., Kurosu, T. P., Chance, K., Heald, C. L., and Guenther, A.: Spatial distribution of isoprene emissions from North America derived from formaldehyde column measurements by the OMI satellite sensor, J. Geophys. Res., 113, D02307, doi:10.1029/2007JD008950, 2008a.

Millet, D. B., Jacob, D. J., Custer, T. G., Gouw, J. A. d., Goldstein, A. H., Karl, T., Singh, H. B., Sive, B. C., Talbot, R. W., Warneke, C., and Williams, J.: New constraints on terrestrial and oceanic sources of atmospheric methanol, Atmos. Chem. Phys., 8, 68876905, 2008b,

http://www.atmos-chem-phys.net/8/6887/2008/.

Millet, D. B., Atlas, E. L., Blake, D. R., Blake, N. J., Diskin, G. S., Holloway, J. S., Meinardi, S., Ryerson, T. B., and Sachse, G. W.: Halocarbon emissions from the United States and Mexico and their global warming potential, Environ. Sci. Technol., 43, 1055-1060, 2009.

Molina, L. T., Madronich, S., Gaffney, J. S., Apel, E., Foy, B. d., Fast, J., Ferrare, R., Herndon, S., Jimenez, J. L., Lamb, B., Osornio-Vargas, A. R., Russell, P., Schauer, J. J., Stevens, P. S., and Zavala, M.: An overview of the MILAGRO 2006 campaign: Mexico City emissions and their transport and transformation, Atmos. Chem. Phys. Discuss., 10, 7819-7983, 2010, http://www.atmos-chem-phys-discuss.net/10/7819/2010/.

Montegut, C. D., Madec, G., Fischer, A. S., Lazar, A., and Iudicone, D.: Mixed layer depth over the global ocean: An examination of profile data and a profile-based climatology, J. Geophys. Res.Ocean., 109, C12003, doi:10.1029/2004JC002378, 2004.

Mopper, K. and Kieber, D. J.: Distribution and biological turnover of dissolved organic compounds in the water column of the Black Sea, Deep-Sea Res., 38, S1021-S1047, 1991.

Nelson, N. B., Siegel, D. A., and Michaels, A. F.: Seasonal dynamics of colored dissolved material in the Sargasso Sea, Deep-Sea Res. Pt. I, 45, 931-957, 1998.

Nelson, N. B., Siegel, D. A., Carlson, C. A., Swan, C., Smethie, W. M., and Khatiwala, S.: Hydrography of chromophoric dissolved organic matter in the North Atlantic, Deep-Sea Res. Pt. I, 54, 710-731, 2007.

Northway, M. J., de Gouw, J. A., Fahey, D. W., Gao, R. S., Warneke, C., Roberts, J. M., and Flocke, F.: Evaluation of the role of heterogeneous oxidation of alkenes in the detection of atmospheric acetaldehyde, Atmos. Environ., 38, 6017-6028, 2004.

Olivier, J., Peters, J., Granier, C., Petron, G., Muller, J. F., and Wallens, S.: Present and future surface emissions of atmospheric compounds, POET report \#2, EU project EVK2-1999-00011, 2003.

Parrish, D. D., Kondo, Y., Cooper, O. R., Brock, C. A., Jaffe, D. A., Trainer, M., Ogawa, T., Hubler, G., and Fehsenfeld, F. C.: Intercontinental Transport and Chemical Transformation 2002 (ITCT 2K2) and Pacific Exploration of Asian Continental Emission (PEACE) experiments: An overview of the 2002 winter and spring intensives, J. Geophys. Res., 109, D23S01, doi:10.1029/2004JD004980, 2004.

Parrish, D. D., Allen, D. T., Bates, T. S., Estes, M., Fehsenfeld, F. C., Feingold, G., Ferrare, R., Hardesty, R. M., Meagher, J. F., Nielsen-Gammon, J. W., Pierce, R. B., Ryerson, T. B., Seinfeld, J. H., and Williams, E. J.: Overview of the Second Texas Air
Quality Study (TexAQS II) and the Gulf of Mexico Atmospheric Composition and Climate Study (GoMACCS), J. Geophys. Res., 114, D00F13, doi:10.1029/2009JD011842, 2009.

Paulson, S. E., Flagan, R. C., and Seinfeld, J. H.: Atmospheric photooxidation of isoprene. Part II: The ozone-isoprene reaction, Int. J. Chem. Kin., 24, 103-125, 1992.

Randerson, J. T., Thompson, M. V., Conway, T. J., Fung, I. Y., and Field, C. B.: The contribution of terrestrial sources and sinks to trends in the seasonal cycle of atmospheric carbon dioxide, Global Biogeochem. Cy., 11, 535-560, 1997.

Randerson, J. T., van der Werf, G. R., Giglio, L., Collatz, G. J., and Kasibhatla, P. S.: Global Fire Emissions Database, Version 2 (GFEDv2), Oak Ridge National Laboratory Distributed Active Archive Center (idoi:10.3334/ORNLDAAC/834), Oak Ridge, TN, USA, 2006.

Raper, J. L., Kleb, M. M., Jacob, D. J., Davis, D. D., Newell, R. E., Fuelberg, H. E., Bendura, R. J., Hoell, J. M., and McNeal, R. J.: Pacific Exploratory Mission in the tropical Pacific: PEMTropics B, March-April 1999, J. Geophys. Res., 106, 3240132425, 2001.

Roberts, J. M.: The atmospheric chemistry of organic nitrates, Atmos. Environ., 24A, 243-287, 1990.

Rottenberger, S., Kuhn, U., Wolf, A., Schebeske, G., Oliva, S. T., Tavares, T. M., and Kesselmeier, J.: Exchange of short-chain aldehydes between Amazonian vegetation and the atmosphere, Ecol. Appl., 14, S247-S262, 2004.

Rottenberger, S., Kuhn, U., Wolf, A., Schebeske, G., Oliva, S. T., Tavares, T. M., and Kesselmeier, J.: Formaldehyde and acetaldehyde exchange during leaf development of the Amazonian deciduous tree species Hymenaea courbaril, Atmos. Environ., 39, 2275-2279, 2005.

Rottenberger, S., Kleiss, B., Kuhn, U., Wolf, A., Piedade, M. T. F., Junk, W., and Kesselmeier, J.: The effect of flooding on the exchange of the volatile C-2-compounds ethanol, acetaldehyde and acetic acid between leaves of Amazonian floodplain tree species and the atmosphere, Biogeosciences, 5, 1085-1100, 2008, http://www.biogeosciences.net/5/1085/2008/.

Sander, S. P., Friedl, R. R., Golden, D. M., Kurylo, M. J., Moortgat, G. K., Wine, P. H., Ravishankara, A. R., Kolb, C. E., Molina, M. J., Finlayson-Pitts, B. J., Huie, R. E., and Orkin, V. L.: Chemical kinetics and photochemical data for use in atmospheric studies: Evaluation number 15, JPL Publication 02-25, Jet Propulsion Laboratory, Pasadena, USA, 2006.

Schade, G. W. and Goldstein, A. H.: Fluxes of oxygenated volatile organic compounds from a ponderosa pine plantation, J. Geophys. Res., 106, 3111-3123, 2001.

Schade, G. W. and Goldstein, A. H.: Plant physiological influences on the fluxes of oxygenated volatile organic compounds from ponderosa pine trees, J. Geophys. Res., 107, 4082, doi:10.1029/2001JD000532, 2002.

Schnitzler, J. P., Bauknecht, N., Bruggemann, N., Einig, W., Forkel, R., Hampp, R., Heiden, A. C., Heizmann, U., Hoffmann, T., Holzke, C., Jaeger, L., Klauer, M., Komenda, M., Koppmann, R., Kreuzwieser, J., Mayer, H., Rennenberg, H., Smiatek, G., Steinbrecher, R., Wildt, J., and Zimmer, W.: Emission of biogenic volatile organic compounds: An overview of field, laboratory and modelling studies performed during the 'Tropospheric Research Program' (TFS) 1997-2000, J. Atmos. Chem., 42, 159177, 2002. 
Siegel, D. A., Maritorena, S., Nelson, N. B., Hansell, D. A., and Lorenzi-Kayser, M.: Global distribution and dynamics of colored dissolved and detrital organic materials, J. Geophys. Res.Ocean., 107, 3228, doi:10.1029/2001JC000965, 2002.

Siegel, D. A., Maritorena, S., Nelson, N. B., and Behrenfeld, M. J.: Independence and interdependencies among global ocean color properties: Reassessing the bio-optical assumption, J. Geophys. Res.-Ocean., 110, C07011, doi:10.1029/2004JC002527, 2005.

Singh, H., Chen, Y., Staudt, A., Jacob, D., Blake, D., Heikes, B., and Snow, J.: Evidence from the Pacific troposphere for large global sources of oxygenated organic compounds, Nature, 410, 1078-1081, 2001.

Singh, H. B., Kanakidou, M., Crutzen, P. J., and Jacob, D. J.: High concentrations and photochemical fate of oxygenated hydrocarbons in the global troposphere, Nature, 378, 50-54, 1995.

Singh, H. B., Tabazadeh, A., Evans, M. J., Field, B. D., Jacob, D. J., Sachse, G., Crawford, J. H., Shetter, R., and Brune, W. H.: Oxygenated volatile organic chemicals in the oceans: Inferences and implications based on atmospheric observations and air-sea exchange models, Geophys. Res. Lett., 30, 1862, doi:10.1029/2003GL017933, 2003.

Singh, H. B., Salas, L. J., Chatfield, R. B., Czech, E., Fried, A., Walega, J., Evans, M. J., Field, B. D., Jacob, D. J., Blake, D., Heikes, B., Talbot, R., Sachse, G., Crawford, J. H., Avery, M. A., Sandholm, S., and Fuelberg, H.: Analysis of the atmospheric distribution, sources, and sinks of oxygenated volatile organic chemicals based on measurements over the Pacific during TRACE-P, J. Geophys. Res., 109, D15S07, doi:10.1029/2003JD003883, 2004.

Singh, H. B., Brune, W. H., Crawford, J. H., Jacob, D. J., and Russell, P. B.: Overview of the summer 2004 intercontinental chemical transport experiment - North America (INTEX-A), J. Geophys. Res., 111, D24S01, doi:10.1029/2006JD007905, 2006.

Singh, H. B., Brune, W. H., Crawford, J. H., Flocke, F., and Jacob, D. J.: Chemistry and transport of pollution over the Gulf of Mexico and the Pacific: spring 2006 INTEX-B campaign overview and first results, Atmos. Chem. Phys., 9, 2301-2318, 2009, http://www.atmos-chem-phys.net/9/2301/2009/.

Sinha, V., Williams, J., Meyerhofer, M., Riebesell, U., Paulino, A. I., and Larsen, A.: Air-sea fluxes of methanol, acetone, acetaldehyde, isoprene and DMS from a Norwegian fjord following a phytoplankton bloom in a mesocosm experiment, Atmos. Chem. Phys., 7, 739-755, 2007, http://www.atmos-chem-phys.net/7/739/2007/.

Slemr, J., Junkermann, W., and VolzThomas, A.: Temporal variations in formaldehyde, acetaldehyde and acetone and budget of formaldehyde at a rural site in southern Germany, Atmos. Environ., 30, 3667-3676, 1996.

Slusher, D. L., Huey, L. G., Tanner, D. J., Flocke, F. M., and Roberts, J. M.: A thermal dissociation-chemical ionization mass spectrometry (TD-CIMS) technique for the simultaneous measurement of peroxyacyl nitrates and dinitrogen pentoxide, J. Geophys. Res., 109, D19315, doi:10.1029/2004JD004670, 2004.

Solberg, S., Dye, C., Schmidbauer, N., Herzog, A., and Gehrig, R.: Carbonyls and nonmethane hydrocarbons at rural European sites from the Mediterranean to the Arctic, J. Atmos. Chem., 25, 3366, 1996.

Sommariva, R., de Gouw, J. A., Trainer, M., Atlas, E., Goldan, P. D., Kuster, W. C., Warneke, C., and Fehsenfeld, F. C.: Emis- sions and photochemistry of oxygenated VOCs in urban plumes in the Northeastern United States, Atmos. Chem. Phys. Disc., 8, 12371-12408, 2008.

Staudt, A. C., Jacob, D. J., Ravetta, F., Logan, J. A., Bachiochi, D., Krishnamurti, T. N., Sandholm, S., Ridley, B., Singh, H. B., and Talbot, B.: Sources and chemistry of nitrogen oxides over the tropical Pacific, J. Geophys. Res., 108, 8239, doi:10.1029/2002JD002139, 2003.

Swan, C. M., Siegel, D. A., Nelson, N. B., Carlson, C. A., and Nasir, E.: Biogeochemical and hydrographic controls on chromophoric dissolved organic matter distribution in the Pacific Ocean, DeepSea Res. Pt. I, 54, 710-731, 2009.

Taraborrelli, D., Lawrence, M. G., Butler, T. M., Sander, R., and Lelieveld, J.: Mainz Isoprene Mechanism 2 (MIM2): an isoprene oxidation mechanism for regional and global atmospheric modelling, Atmos. Chem. Phys., 9, 2751-2777, 2009, http://www.atmos-chem-phys.net/9/2751/2009/.

Tyndall, G. S., Cox, R. A., Granier, C., Lesclaux, R., Moortgat, G. K., Pilling, M. J., Ravishankara, A. R., and Wallington, T. J.: Atmospheric chemistry of small organic peroxy radicals, J. Geophys. Res., 106, 12157-12182, 2001.

van der Werf, G. R., Randerson, J. T., Giglio, L., Collatz, G. J., Kasibhatla, P. S., and Arellano, A. F.: Interannual variability in global biomass burning emissions from 1997 to 2004, Atmos. Chem. Phys., 6, 3423-3441, 2006,

http://www.atmos-chem-phys.net/6/3423/2006/.

Vestreng, V. and Klein, H.: Emission data reported to UNECE/EMEP: Quality assurance and trend analysis \& Presentation of WebDab, MSC-W Status Report 2002, Norwegian Meteorological Institute, Oslo, 2002.

Warneke, C., Karl, T., Judmaier, H., Hansel, A., Jordan, A., Lindinger, W., and Crutzen, P. J.: Acetone, methanol, and other partially oxidized volatile organic emissions from dead plant matter by abiological processes: Significance for atmospheric $\mathrm{HO}_{\mathrm{x}}$ chemistry, Global Biogeochem. Cy., 13, 9-17, 1999.

Warneke, C., Luxembourg, S. L., de Gouw, J. A., Rinne, H. J. I., Guenther, A. B., and Fall, R.: Disjunct eddy covariance measurements of oxygenated volatile organic compounds fluxes from an alfalfa field before and after cutting, J. Geophys. Res., 107, 4067, 10.1029/2001JD000594, 2002.

Warneke, C., McKeen, S. A., de Gouw, J. A., Goldan, P. D., Kuster, W. C., Holloway, J. S., Williams, E. J., Lerner, B. M., Parrish, D. D., Trainer, M., Fehsenfeld, F. C., Kato, S., Atlas, E. L., Baker, A., and Blake, D. R.: Determination of urban volatile organic compound emission ratios and comparison with an emissions database, J. Geophys. Res., 112, D10S47, doi:10.1029/2006JD007930, 2007.

Weinheimer, A. J., Walega, J. G., Ridley, B. A., Sachse, G. W., Anderson, B. E., and Collins, J. E.: Stratospheric $\mathrm{NO}_{\mathrm{y}}$ measurements on the NASA DC-8 during AASE-II, Geophys. Res. Lett., 20, 2563-2566, 1993.

Winters, A. J., Adams, M. A., Bleby, T. M., Rennenberg, H., Steigner, D., Steinbrecher, R., and Kreuzwieser, J.: Emissions of isoprene, monoterpene and short-chained carbonyl compounds from Eucalyptus spp. in southern Australia, Atmos. Environ., 43, 3035-3043, 2009.

Xiao, Y. P., Logan, J. A., Jacob, D. J., Hudman, R. C., Yantosca, R., and Blake, D. R.: Global budget of ethane and regional constraints on US sources, J. Geophys. Res., 113, D21306, 
doi:10.1029/2007JD009415, 2008.

Yang, W., Shabanov, N. V., Huang, D., Wang, W., Dickinson, R. E., Nemani, R. R., Knyazikhin, Y., and Myneni, R. B.: Analysis of leaf area index products from combination of MODIS Terra and Aqua data, Remote Sensing of Environment, 104, 297-312, 2006.

Yevich, R. and Logan, J. A.: An assessment of biofuel use and burning of agricultural waste in the developing world, Global Biogeochem. Cy., 17, 1095, doi:10.1029/2002GB001952, 2003.

Yokelson, R. J., Christian, T. J., Karl, T. G., and Guenther, A.: The tropical forest and fire emissions experiment: laboratory fire measurements and synthesis of campaign data, Atmos. Chem. Phys., 8, 3509-3527, 2008, http://www.atmos-chem-phys.net/8/3509/2008/.

Zavala, M., Herndon, S. C., Wood, E. C., Jayne, J. T., Nelson, D. D., Trimborn, A. M., Dunlea, E., Knighton, W. B., Mendoza, A., Allen, D. T., Kolb, C. E., Molina, M.J., and Molina, L. T.: Comparison of emissions from on-road sources using a mobile laboratory under various driving and operational sampling modes, Atmos. Chem. Phys., 9, 1-14, 2009,

http://www.atmos-chem-phys.net/9/1/2009/.
Zhang, J. F. and Smith, K. R.: Emissions of carbonyl compounds from various cookstoves in China, Environ. Sci. Technol., 33, 2311-2320, 1999.

Zhang, Q., Streets, D. G., Carmichael, G. R., He, K. B., Huo, H., Kannari, A., Klimont, Z., Park, I. S., Reddy, S., Fu, J. S., Chen, D., Duan, L., Lei, Y., Wang, L. T., and Yao, Z. L.: Asian emissions in 2006 for the NASA INTEX-B mission, Atmos. Chem. Phys., 9, 5131-5153, 2009, http://www.atmos-chem-phys.net/9/5131/2009/.

Zhou, X. L. and Mopper, K.: Photochemical production of lowmolecular-weight carbonyl compounds in seawater and surface microlayer and their air-sea exchange, Mar. Chem., 56, 201-213, 1997. 